Article

\title{
Wavelength Dependence of the Transformation Mechanism of Sulfonamides Using Different LED Light Sources and $\mathrm{TiO}_{2}$ and ZnO Photocatalysts
}

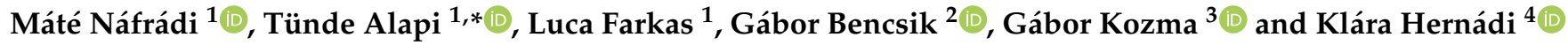 \\ 1 Department of Inorganic and Analytical Chemistry, University of Szeged, Dóm tér 7, \\ H-6720 Szeged, Hungary; nafradim@chem.u-szeged.hu (M.N.); fluca@chem.u-szeged.hu (L.F.) \\ 2 Department of Physical Chemistry and Materials Science, University of Szeged, Rerrich Béla tér 1, \\ H-6720 Szeged, Hungary; bencsikg@chem.u-szeged.hu \\ 3 Department of Applied and Environmental Chemistry, University of Szeged, Rerrich Béla tér 1, \\ H-6720 Szeged, Hungary; kozmag@chem.u-szeged.hu \\ 4 Institute of Physical Metallurgy, Metal Forming and Nanotechnology, University of Miskolc, C/2-5 Building 209, \\ H-3515 Miskolc-Egyetemvaros, Hungary; femhernadi@uni-miskolc.hu \\ * Correspondence: alapi@chem.u-szeged.hu
}

Citation: Náfrádi, M.; Alapi, T.; Farkas, L.; Bencsik, G.; Kozma, G.; Hernádi, K. Wavelength Dependence of the Transformation Mechanism of Sulfonamides Using Different LED Light Sources and $\mathrm{TiO}_{2}$ and $\mathrm{ZnO}$ Photocatalysts. Materials 2022, 15, 49. https://doi.org/10.3390/ma15010049

Academic Editors: Alina Pruna, Klára Hernádi, Zsolt Pap and Tünde Alapi

Received: 4 December 2021

Accepted: 21 December 2021

Published: 22 December 2021

Publisher's Note: MDPI stays neutral with regard to jurisdictional claims in published maps and institutional affiliations.

Copyright: (C) 2021 by the authors. Licensee MDPI, Basel, Switzerland. This article is an open access article distributed under the terms and conditions of the Creative Commons Attribution (CC BY) license (https:// creativecommons.org/licenses/by/ $4.0 /)$.
Abstract: The comparison of the efficiency of the commercially available photocatalysts, $\mathrm{TiO}_{2}$ and $\mathrm{ZnO}$, irradiated with $365 \mathrm{~nm}$ and $398 \mathrm{~nm}$ light, is presented for the removal of two antibiotics, sulfamethazine (SMT) and sulfamethoxypyridazine (SMP). The ${ }^{\bullet} \mathrm{OH}$ formation rate was compared using coumarin, and higher efficiency was proved for $\mathrm{TiO}_{2}$ than $\mathrm{ZnO}$, while for 1,4-benzoquinone in $\mathrm{O}_{2}$-free suspensions, the higher contribution of the photogenerated electrons to the conversion was observed for $\mathrm{ZnO}$ than $\mathrm{TiO}_{2}$, especially at $398 \mathrm{~nm}$ irradiation. An extremely fast transformation and high quantum yield of SMP in the $\mathrm{TiO}_{2} / \mathrm{LED}_{398 \mathrm{~nm}}$ process were observed. The transformation was fast in both $\mathrm{O}_{2}$ containing and $\mathrm{O}_{2}$-free suspensions and takes place via desulfonation, while in other cases, mainly hydroxylated products form. The effect of reaction parameters (methanol, dissolved $\mathrm{O}_{2}$ content, $\mathrm{HCO}_{3}{ }^{-}$and $\mathrm{Cl}^{-}$) confirmed that a quite rarely observed energy transfer between the excited state P25 and SMP might be responsible for this unique behavior. In our opinion, these results highlight that "non-conventional" mechanisms could occur even in the case of the well-known $\mathrm{TiO}_{2}$ photocatalyst, and the effect of wavelength is also worth investigating.

Keywords: energy transfer; direct charge transfer; matrix effect; sulfonamides

\section{Introduction}

The release of antimicrobial agents to the environment causes several environmental, ecological, and public health problems [1,2]. Infection caused by antibiotic-resistant bacteria results in more than 33,000 deaths in Europe. Sulfonamides are among the first synthesized and frequently used antibiotics in human and veterinary medicine and, similar to the other antibiotics, highly contribute to the emergence of antibiotic-resistant bacteria [3]. Existing wastewater treatment plants are not designed to remove micropollutants $[4,5]$; the raw and treated wastewaters carry significant amount of antibiotic-resistant bacteria. Thus, the application of cost-effective additive water treatment methods is required to eliminate the antibiotics from treated waters completely. Advanced Oxidation Processes (AOPs) offer a solution to remove trace amounts of recalcitrant organic pollutants from wastewater. Among other AOPs, heterogeneous photocatalysis has been applied to remove several sulfonamides, using different photocatalysts and light sources [6-17].

During heterogeneous photocatalysis, a photon with energy higher than the bandgap is absorbed by a semiconductor, forming a photogenerated conduction band electron $\left(\mathrm{e}_{\mathrm{CB}}{ }^{-}\right)$ and a valence band hole $\left(\mathrm{h}_{\mathrm{VB}}{ }^{+}\right)$, which react with dissolved organic compounds via direct charge transfer reactions or generate different reactive oxygen species (ROS) [18,19], 
of which hydroxyl radical $\left(\bullet^{\bullet} \mathrm{OH}\right)$ has primary importance. The rare examples of photocatalytic reactions induced by prevailing energy transfer have been recently reported in literature by considering the excited solid semiconductor as the energy donor. While electron transfer requires direct contact between the semiconductor and the substrate, mediated contact or a certain distance can favor energy transfer [20]. Nosaka et al. explained the formation of singlet oxygen via double electron transfer in the opposite direction [21], while other authors hypothesized energy transfer, even in the case of surface-modified $\mathrm{TiO}_{2}$ [22,23]. The enhanced transformation of cyanuric acid [22], the selective oxidization of limonene [24,25], and isomerization of caffeic acid in aqueous $\mathrm{TiO}_{2}$ suspensions were interpreted by energy transfer mechanism [26]. In the case of "trivial energy transfer," the quenching of the excited semiconductor can occur by the emission of a photon, and the energy transfer to the species takes place by absorption of the emitted photon. Unlike the trivial mechanism, Förster and Dexter energy transfers are radiationless processes, and their manifestation depends strongly on the distance of the acceptor from the semiconductor [20].

The two most often investigated photocatalysts, $\mathrm{TiO}_{2}$ and $\mathrm{ZnO}$, have several favorable properties but are mainly active in the $\mathrm{UV}$ region. The commercially available $\mathrm{TiO}_{2}$ photocatalyst, P25, contains two crystal phases: the bandgap of rutile is $3.0 \mathrm{eV}$, while the anatase phase is $3.2 \mathrm{eV}$, which is approximately equal to the $\mathrm{ZnO}$ bandgap [27-29]. The excellent photocatalytic activity of $\mathrm{P}^{25} \mathrm{TiO}_{2}$ is often attributed to its mixed crystal phases. Some authors observed individual anatase- and rutile-phase $\mathrm{TiO}_{2}$ particles without a heterojunction structure [30,31], while others observed a mixture of amorphous $\mathrm{TiO}_{2}$ with anatase or rutile phase and/or anatase particles covered by a thin overlayer of rutile [32-36]. Ohtani et al. proved the absence of synergetic effect, and found that P25 is a simple mixture of anatase and rutile without any interactions $[37,38]$. On the contrary, under visible light $(>400 \mathrm{~nm})$ irradiation, the superior photocatalytic activity of P25 was originated from the anatase-rutile interparticle contact, which is beneficial to the charge carrier separation and consequently the efficiency $[33,36,39,40]$. A comprehensive understanding of P25 microstructure should be crucial for designing an efficient $\mathrm{TiO}_{2}$-based photocatalyst.

Nowadays, many researchers are involved in synthesizing and characterizing new materials or composite materials based on $\mathrm{TiO}_{2}$ [41-43] or $\mathrm{ZnO}[29,44-47]$, which can be used as effective photocatalysts. However, the use of these new visible light-active photocatalysts often faces a number of problems, such as low quantum efficiency, photocorrosion, or photodissolution, or a high degree of selectivity to remove organic matter [48]. The efficiency of $\mathrm{TiO}_{2}$ and $\mathrm{ZnO}$ as photocatalysts applied for the elimination of organic trace pollutants under $\mathrm{UV}$ radiation is not easy to exceed. $\mathrm{TiO}_{2}$ and $\mathrm{ZnO}$ were investigated to transform various sulfonamides $[4,15-17,49,50]$. Both catalysts were effective; however, the efficiency depended on the chemical structure of sulfonamide, and generally, $\mathrm{TiO}_{2} \mathrm{P} 25$ provided better efficiency than $\mathrm{ZnO}$, especially in the presence of $\mathrm{H}_{2} \mathrm{O}_{2}$ [16]. Comparing the efficiency of heterogeneous photocatalysis to other AOPs, sulfonamide degradation is highly cost-effective for ozonation, but toxic, ozone resistant intermediates forms, while using $\mathrm{TiO}_{2}$ or $\mathrm{ZnO}$, the mineralization is also efficient. Several visible light-activated photocatalysts ( $\mathrm{g}-\mathrm{C}_{3} \mathrm{~N}_{4}$ [10,14], $\mathrm{Bi}_{2} \mathrm{O}_{4}$ [12], $\mathrm{Bi}_{2} \mathrm{MoO}_{6} / \mathrm{Bi}_{2} \mathrm{WO}_{6}$ [13], $\mathrm{WO}_{3}$ [11]; $\mathrm{Ce}_{\mathrm{x}} \mathrm{Zr}_{\mathrm{y}} \mathrm{O}_{2}$ [7]) were also tested with sulfonamides, with usually lower efficiency compared to $\mathrm{TiO}_{2}$ and $\mathrm{ZnO}$, although some promising results can also be found. The efficiency of $\mathrm{BiOI} / \mathrm{BiOCl}$ composite photocatalyst for the degradation of SMP and methyl orange under UV (398 nm) and visible light irradiation was comparable to $\mathrm{TiO}_{2} \mathrm{P} 25$, but highly toxic intermediates were accumulated opposite to the P25, which was efficient for mineralization and toxicity decrease [51]. Besides developing new photocatalysts, using more efficient light sources such as UV or UV/Vis LEDs, and advanced reactor designs may enhance the cost efficiency of the method $[19,52,53]$. In addition to their many advantages, one of the benefits of LEDs [54-56] is that they emit their photons over a relatively narrow wavelength range to be well adapted to the absorption properties of photocatalysts and provide an opportunity to handle the wavelength-depending effects easily [57-60]. 
One of the barriers to the practical application of heterogeneous photocatalysis is the adverse effect of the matrix and its parameters on efficiency. Dissolved organic matter and inorganic ions may act as UV filters, radical scavengers or adsorbing on the catalysts' surface can occupy the active sites and reduce efficiency [61-64]. Besides the adverse effects, the adsorption of some ions might result in better charge separation, or their reaction with photogenerated charge carriers results in the formation of less reactive and more selective radicals (e.g., $\mathrm{Cl}^{\bullet}, \mathrm{CO}_{3}^{\bullet-}, \mathrm{SO}_{4}^{\bullet-}$ ) than ${ }^{\bullet} \mathrm{OH}$ which could contribute to the transformation of given organic pollutants [61,65-68].

The current research aimed to compare the efficiency of the commercially available photocatalysts, $\mathrm{TiO}_{2}$ and $\mathrm{ZnO}$, irradiated with two LED light sources; a high power UVA LED emitting at $365 \mathrm{~nm}\left(\mathrm{LED}_{365 \mathrm{~nm}}\right)$ and a cheap commercial LED-tape emitting at $398 \mathrm{~nm}\left(\mathrm{LED}_{398 \mathrm{~nm}}\right)$. The removal of two sulfonamide antibiotics, sulfamethazine (SMT) and sulfamethoxypyridazine (SMP), was investigated in detail and compared based on removal and mineralization rates. The direct detection of reactive species in the case of heterogeneous photocatalysis is rather difficult; however, the knowledge of their formation rate under given circumstances is crucial for the elucidation of degradation mechanism and the assessment of photocatalytic activity. The ${ }^{\bullet} \mathrm{OH}$ formation rates were compared using coumarin (COU) as a model compound. The rate and importance of the direct charge transfer process were compared using 1,4-benzoquinone (1,4-BQ) in $\mathrm{O}_{2}$-free suspensions. The formation of organic and inorganic degradation products of sulfonamides and the ecotoxicity of the treated solutions were also investigated. Experiments were performed in real water matrices (tap water and biologically treated wastewater), and the effect of methanol as ${ }^{\bullet} \mathrm{OH}$ scavenger and the most abundant anions $\left(\mathrm{Cl}^{-}, \mathrm{HCO}_{3}{ }^{-}\right)$of the matrices was also investigated.

\section{Materials and Analytical Methods}

\subsection{Photochemical Experiments}

Two photoreactors were used during the photocatalytic experiments. One was equipped with 12 high-power UV-A LED light sources (Vishay, Malvern, PA, USA; VLMU3510-365-130, 0.69 W radiant power at 2.0 W electric power input) emitting at 365 $\mathrm{nm}\left(\mathrm{LED}_{365 \mathrm{~nm}}\right)$. A laboratory power supply (Axiomet, Malmö, Sweden; AX-3005DBL-3; maximum output $5.0 \mathrm{~A} / 30.0 \mathrm{~V}$ ) was used to control the electrical power uptake of the light sources $(6.6 \mathrm{~W})$. Irradiations were performed in a $200 \mathrm{~cm}^{3}$ cylindrical glass reactor placed inside the hexagonally arranged LEDs (Figure S1a). The solutions were bubbled with gas from a porous glass filter. Synthetic air or $\mathrm{N}_{2}(99.995 \%)$ was used depending on the measurements.

The other photochemical reactor was equipped with commercial UV-LED tapes (LEDmaster, Szeged, Hungary; $4.6 \mathrm{~W}$ electric power input; 60 diodes $/ \mathrm{m}$ ) fixed on the inside of a double-walled, water-cooled reactor $\left(\mathrm{LED}_{398 \mathrm{~nm}}\right)$ (Figure S1b). Solutions were irradiated in a $100 \mathrm{~cm}^{3}$ glass reactor; the suspension was bubbled with synthetic air. The emission spectra of both light sources have been measured using a two-channel fiber-optic AvaSpec-FT2048 CCD spectrometer (Avantes, Nehterlands).

Two commercially available photocatalysts were used during the experiments, $\mathrm{TiO}_{2}$ Aeroxide ${ }^{\circledR}$ P25 and $\mathrm{ZnO}$. When not stated otherwise, the concentration of the photocatalyst suspensions was $1.00 \mathrm{~g} \mathrm{dm}^{-3}$ and $1.0 \times 10^{-4} \mathrm{M}$ solutions of COU, SMT, and SMP and $2.0 \times 10^{-4} \mathrm{M}$ solutions of 1,4-BQ were irradiated. The suspension was stirred and bubbled with air or $\mathrm{N}_{2}$ for $30 \mathrm{~min}$ in the dark; and the measurement was started by turning on the light source. Before analysis, the samples were centrifuged (Dragonlab, Beijing, China, 15,000 RPM) and filtered using syringe filters (FilterBio, FilterBio Nantong, China; PVDF-L; $0.22 \mu \mathrm{m}$ ).

\subsection{Analytical Methods}

X-ray diffractometry (XRD) measurements were performed with a Rigaku Miniflex II (Rigaku, Tokyo, Japan; $\mathrm{Cu} \mathrm{K} \alpha$ radiation source, 3.0-90.0 2Theta ${ }^{\circ}$ range, with 4.0 $2 \mathrm{Theta}^{\circ} \mathrm{min}^{-1}$ resolution). The specific surface area was determined via $\mathrm{N}_{2}$ adsorption/desorption 
isotherms using a Quantachrome NOVA 2200 analyzer (Quantachrome, Boynton Beach, FL, USA). The pore size distribution was calculated by the BJH method. Diffuse reflectance spectroscopy (DRS) was performed using an Ocean Optics USB4000 detector and Ocean Optics DH-2000 light source (Ocean Optics, Largo, FL, USA). The bandgap energy values of the photocatalysts were evaluated by the Kubelka-Munk approach and the Tauc plot. The elemental composition of the photocatalysts was characterized by energy-dispersive X-ray spectroscopy (Hitachi S-4700 operating at $20 \mathrm{kV}$, equipped with a "Röntec" Energy Dispersive Spectrometer with a $12 \mathrm{~mm}$ working distance, Hitachi, Tokyo, Japan).

The photon flux of the light sources was measured using potassium-ferrioxalate actinometry [69]. $1.0 \times 10^{-2} \mathrm{M} \mathrm{Fe}^{3+}$-oxalate solutions were irradiated, the released $\mathrm{Fe}^{2+}$ was measured after complexation with 1,10-phenanthroline. The $\mathrm{Fe}^{2+}$-phenanthroline complex concentration was measured using UV-Vis spectrophotometry (Agilent 8453, Agilent, Santa Clara, CA, USA). During these measurements, the solutions were bubbled with $\mathrm{N}_{2}$.

The concentration of COU was determined using UV-Vis spectrophotometry $\left(\varepsilon_{277 \mathrm{~nm}}=10,293 \mathrm{M}^{-1} \mathrm{~cm}^{-1}\right)$. The concentration of the formed 7-HC was measured using fluorescence spectroscopy (Hitachi F-4500, Hitachi, Tokyo, Japan), the excitation and emission wavelengths were set to $345 \mathrm{~nm}$ and $455 \mathrm{~nm}$, respectively. The concentration of 1,4-benzoquinone (1,4-BQ), its product, the 1,4-hydroquinene (1,4- $\left.\mathrm{H}_{2} \mathrm{Q}\right), \mathrm{SMT}$, and SMP was determined by LC-DAD (Agilent 1100, Agilent, Santa Clara, CA, USA, column: Lichrosphere 100, RP-18; $5 \mu \mathrm{m})$. In the case of 1,4-BQ and 1,4- $\mathrm{H}_{2} \mathrm{Q}$ the eluent consisted of $50 v / v \%$ methanol $(\mathrm{MeOH})$ and $50 \mathrm{v} / \mathrm{v} \%$ water; the flow rate was $1.0 \mathrm{~cm}^{3} \mathrm{~min}^{-1}$, the temperature was set to $25^{\circ} \mathrm{C}$. In the case of SMT and SMP the eluent consisted of $30 v / v \% \mathrm{MeOH}$ and $70 \mathrm{v} / \mathrm{v} \%$ formic acid $(0.1 \mathrm{v} / \mathrm{v} \%)$, the flow rate was $1.00 \mathrm{~cm}^{3} \mathrm{~min}^{-1}$, the temperature was set to $35^{\circ} \mathrm{C}$. The detection of 1,4-BQ, 1,4- $\mathrm{H}_{2} \mathrm{Q}, \mathrm{SMT}$, and SMP was performed at $250 \mathrm{~nm}$, $210 \mathrm{~nm}, 265 \mathrm{~nm}$, and $261 \mathrm{~nm}$, respectively. The retention time was $3.4 \mathrm{~min}, 2.7 \mathrm{~min}, 9.5 \mathrm{~min}$, and $6.1 \mathrm{~min}$. The initial transformation rates of the model compounds $\left(\mathrm{r}_{0}\right)$ were determined from the linear part of the kinetic curves (up to $20 \%$ transformation). Given that the photon flux of light sources and the volume of a treated solution differ, it is worth comparing the efficiency based on apparent quantum yield, calculated by the following equation:

$\Phi=\frac{\text { number of photons reaching the reactor volume }\left(\mathrm{mol}_{\mathrm{photon}} \mathrm{s}^{-1} \mathrm{dm}^{-3}\right)}{\text { number of transformed or formed molecule in the treated volume }\left(\mathrm{mol} \mathrm{s}^{-1} \mathrm{dm}^{-3}\right)}$

The number of photons reaching the reactor volume was calculated from the photon flux of light LEDs divided by the volume of the actinometric solution. The volume of the actinometric solution was the same as the treated suspension.

The determination of SMT and SMP products was achieved by LC-MS, with an Agilent LC/MSD VL mass spectrometer (Agilent, Santa Clara, CA, USA) coupled to the same HPLC. The measurements were performed using an ESI ion source and a triple quadruple analyzer in positive mode ( $3500 \mathrm{~V}$ capillary voltage and $60 \mathrm{~V}$ fragmentor voltage). The drying gas flow rate was $13.0 \mathrm{dm}^{3} \mathrm{~min}^{-1}$, and its temperature was $350{ }^{\circ} \mathrm{C}$. The scanned mass range was between 50-1000 AMU.

Total Organic Carbon (TOC) concentration was determined using an Analytik Jena N/C 3100 analyzer (Analytik Jena, Jena, Germany). The formation of inorganic ions $\left(\mathrm{NH}_{4}{ }^{+}\right.$, $\mathrm{NO}_{2}{ }^{-}, \mathrm{NO}_{3}{ }^{-}$, and $\mathrm{SO}_{4}{ }^{2-}$ ) was measured using ion chromatography (Shimadzu Prominence LC-20AD, Shodex 5U-YS-50 column for cation detection, and Shodex NI-424 5U for anion detection, (Shimadzu, Kyoto, Japan)). The eluent was $4.0 \mathrm{mM}$ methanesulfonic acid and a mixture of $2.5 \mathrm{mM}$ phthalic acid for cation determination and $2.3 \mathrm{mM}$ aminomethane for anion determination. The flow rate of the mobile phase was $1.0 \mathrm{~cm}^{3} \mathrm{~min}^{-1}$.

The performed ecotoxicity tests (LCK480, Hach-Lange GmbH, Berlin, Germany) were based on the bioluminescence inhibition of the luminescent bacteria Vibrio fischeri. Formed $\mathrm{H}_{2} \mathrm{O}_{2}$ was decomposed in the samples by adding catalase enzyme $\left(0.20 \mathrm{mg} \mathrm{dm}^{-3}\right)$ before starting the ecotoxicity tests. The luminescence of the bacteria was measured using a luminometer (Lumistox 300, Hach-Lange $\mathrm{GmbH}$, Berlin, Germany) after 30 min incubation time. 


\subsection{Chemicals and Solvents Used}

Two commercial photocatalysts were used, $\mathrm{TiO}_{2}$ Aeroxid ${ }^{\circledR}$ P25 (Acros Organics, Geel, Belgium, 99.5\%) and ZnO (Sigma Aldrich, St. Louis, MO, USA, 80\%). Experiments were also performed using anatase (Aldrich, St. Louis, MO, USA, 99.8\%) and rutile (Aldrich, St. Louis, MO, USA, 99.9\%) phase $\mathrm{TiO}_{2}$. The list of chemicals used during experimental work can be found in Table S1. Tap water (Szeged, Hungary) and biologically treated domestic wastewater (Szeged, Hungary) were used as mild water matrices; the matrix parameters are summarized in Table S2.

\section{Results and Discussion}

\subsection{The Characterization of the Light Sources and the Photocatalysts}

The photon flux of the light sources was measured using potassium-ferrioxalate actinometry and was similar: $5.52 \times 10^{-6} \mathrm{~mol}_{\text {photon }} \mathrm{s}^{-1}$ for $\mathrm{LED}_{365 \mathrm{~nm}}$ and $4.68 \times 10^{-6} \mathrm{~mol}_{\text {photon }} \mathrm{s}^{-1}$ for $\mathrm{LED}_{398 \mathrm{~nm}}$. The emission spectra of the LED light sources are shown in Figure 1a.
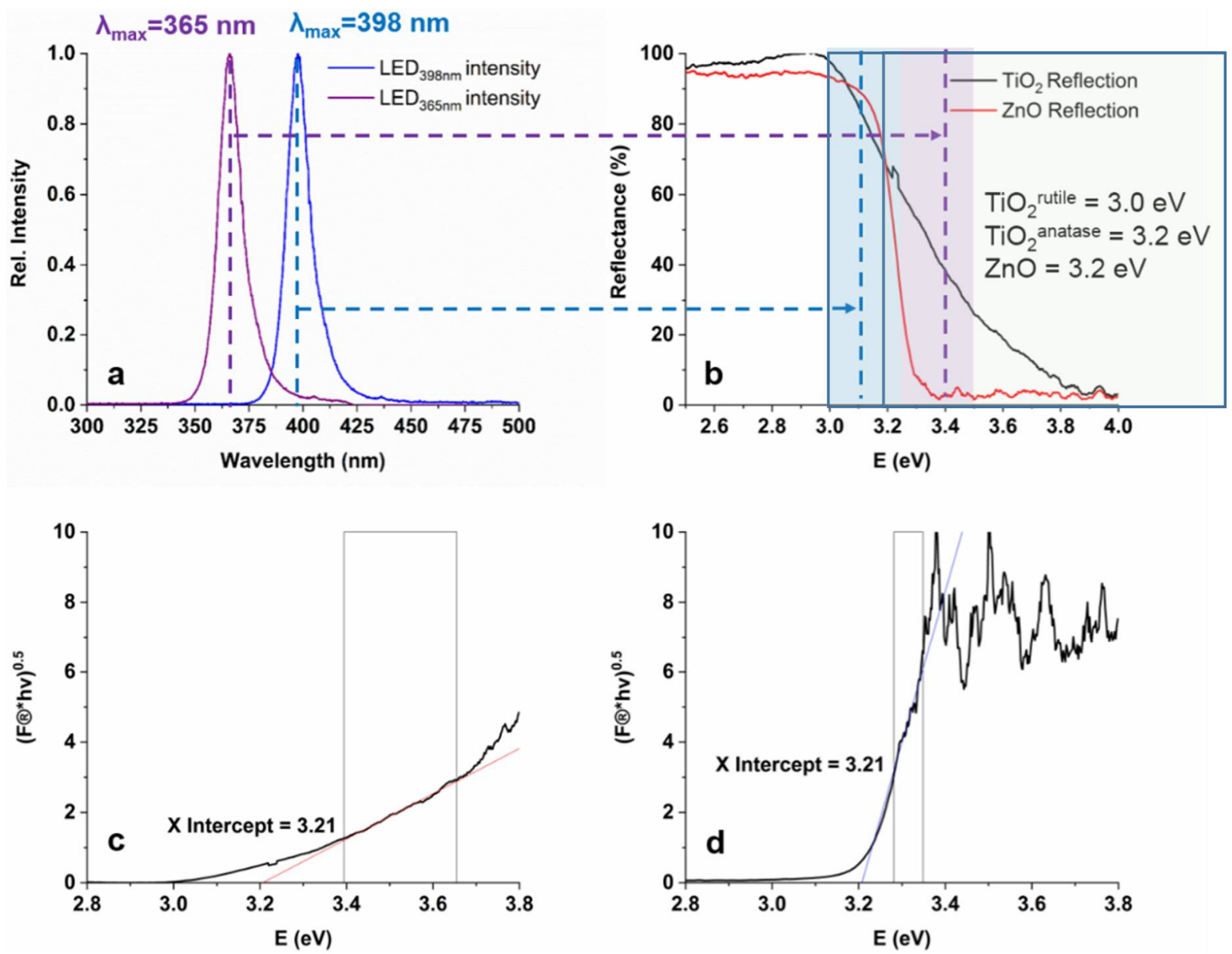

Figure 1. The UV-Vis emission spectra of the LEDs (a), the diffuse reflectance spectra and bandgap energies of $\mathrm{TiO}_{2}$ and $\mathrm{ZnO}(\mathbf{b})$, and the Tauc plot originated from DRS spectra for calculation of band gap energies of $\mathrm{TiO}_{2}(\mathbf{c})$ and $\mathrm{ZnO}(\mathbf{d})$.

Diffuse Reflectance Spectroscopy (DRS) measurements were performed to compare the UV-Vis absorbance and to calculate the bandgap energies of $\mathrm{TiO}_{2}$ and $\mathrm{ZnO}$ (Figure $1 \mathrm{~b}-\mathrm{d}$ ). The calculated band gaps were identical, $3.21 \mathrm{eV}$ for $\mathrm{TiO}_{2}$ and for $\mathrm{ZnO}$. A better light absorption property of $\mathrm{ZnO}$ can be observed in the wavelength range emitted by $\mathrm{LED}_{365 \mathrm{~nm}}$ (350-400 nm); at $365 \mathrm{~nm} \mathrm{TiO} 2$ reflects $40 \%$, while $\mathrm{ZnO}$ practically fully absorbs the photons. Within the wavelength range, emitted by $\mathrm{LED}_{398 \mathrm{~nm}}(380-420 \mathrm{~nm}) \mathrm{ZnO}$ and $\mathrm{TiO}_{2}$ show similar absorption properties; no more than $15-20 \%$ of the $398 \mathrm{~nm}$ photons can be absorbed 
(Figure 1b). For $\mathrm{TiO}_{2}$, the light of $\mathrm{LED}_{398 \mathrm{~nm}}$ can excite mainly the rutile phase having $3.0 \mathrm{eV}$, while $\mathrm{LED}_{365 \mathrm{~nm}}$ can cause the charge separation in rutile and anatase $\mathrm{TiO}_{2}$ and $\mathrm{ZnO}[36,37]$.

The specific surface area and pore-size distribution of $\mathrm{TiO}_{2}$ and $\mathrm{ZnO}$ were measured via $\mathrm{N}_{2}$ adsorption-desorption (Figure 2a). The surface area of $\mathrm{TiO}_{2}$ was significantly higher $\left(64 \mathrm{~m}^{2} \mathrm{~g}^{-1}\right)$ than $\mathrm{ZnO}\left(13 \mathrm{~m}^{2} \mathrm{~g}^{-1}\right)$; both measured values are close to the values given by the suppliers. The average primary particle size for Aeroxide $\mathrm{P}_{2} 5 \mathrm{TiO}_{2}$ is ranges

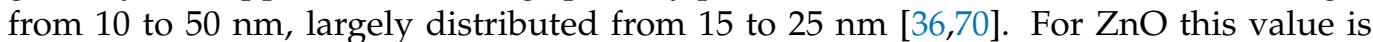
50-70 nm [71]. Element analysis of $\mathrm{ZnO}$ and $\mathrm{TiO}_{2}$ has been measured with EDS technology. For both photocatalysts, the stoichiometric amount of cation (49\% $\mathrm{Zn}$ ad $32 \% \mathrm{Ti}$ for $\mathrm{ZnO}$ and $\mathrm{TiO}_{2}$ respectively) and oxygen (51\% for $\mathrm{ZnO} 68 \%$ for $\mathrm{TiO}_{2}$ ) was measured (within the measurement margin of error). Contaminants were not detected. For $\mathrm{TiO}_{2}$, the XRD pattern is in good agreement with the results reported in the literature; anatase is the dominant crystal phase in the anatase-rutile mixture (Figure 2b) [72,73]. The XRD pattern of ZnO confirmed its pure wurtzite phase (Figure 2b) [44,74].
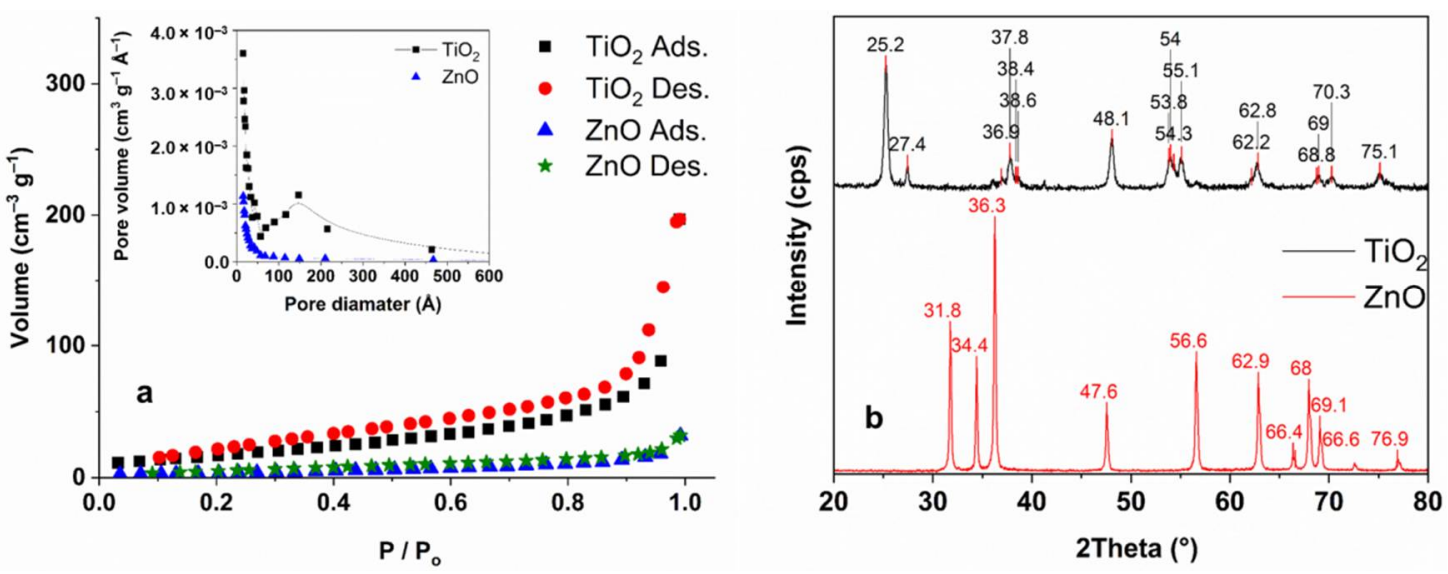

Figure 2. The $\mathrm{N}_{2}$ adsorption-desorption isotherms (a) with corresponding pore-size distribution according to the $\mathrm{BJH}$ model (inset), and the XRD patterns of $\mathrm{TiO}_{2}$ and $\mathrm{ZnO}(\mathbf{b})$.

\subsection{Transformation and Mineralization of Sulfonamides}

At the given initial concentration $\left(1.0 \times 10^{-4} \mathrm{M}\right)$, the adsorption of both SMT and SMP was negligible $(<2 \%)$ for both catalysts. The effect of catalyst concentration was studied in the range of $0.25-1.5 \mathrm{~g} \mathrm{dm}^{-3}$; the transformation rate does not increase above $1.0 \mathrm{~g} \mathrm{dm}^{-3} \mathrm{TiO}_{2}$ and $\mathrm{ZnO}$ concentration (Figure 3); thus, $1.0 \mathrm{~g} \mathrm{dm}^{-3}$ photocatalyst was used for further experiments.
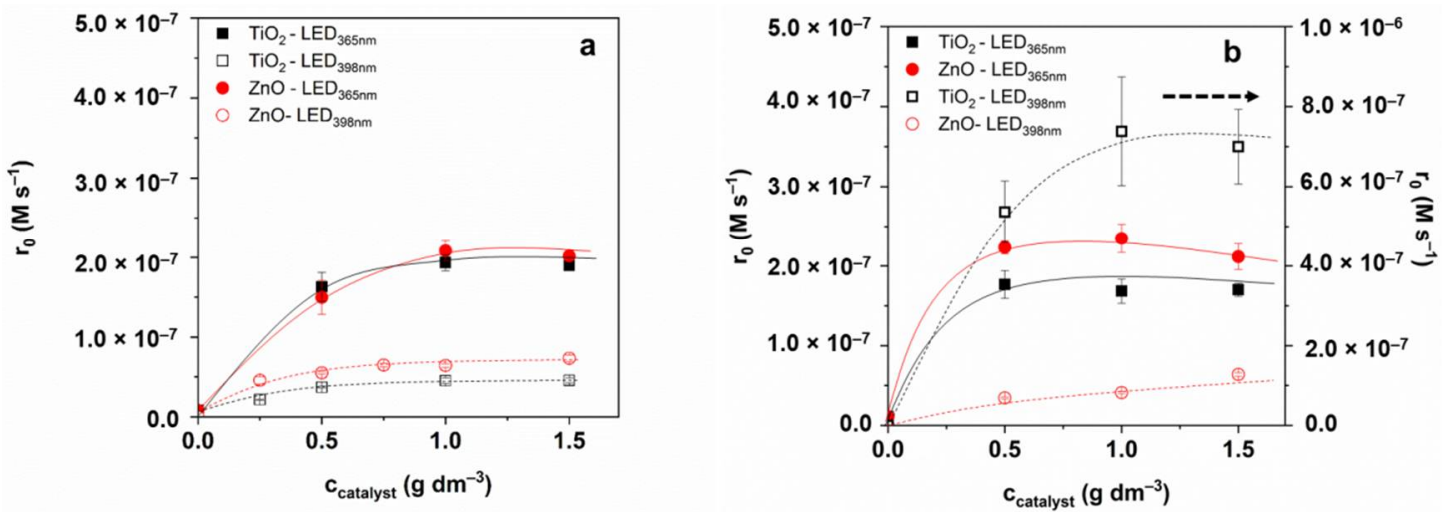

Figure 3. The effect of photocatalyst concentration on the initial transformation rate of SMT (a) and SMP (b).

In the case of SMT, no significant difference was between $\mathrm{TiO}_{2}$ and $\mathrm{ZnO}$, and $\mathrm{LED}_{365 \mathrm{~nm}}$ was more effective than $\mathrm{LED}_{398 \mathrm{~nm}}$ (Figure 3a), as was expected. For SMP, using $\mathrm{LED}_{365 \mathrm{~nm}}$ $\mathrm{ZnO}$ is slightly more efficient than $\mathrm{TiO}_{2}$. Using $\mathrm{TiO}_{2}$ and $\mathrm{LED}_{398 \mathrm{~nm}}$ an extremely fast 
transformation of SMP was observed (Figure 3b), which slows down after 75\% decrease of the initial concentration (Figure $4 \mathrm{~b}$ ). Table 1 . contains the initial reaction rates and the apparent quantum yields calculated at $1.0 \mathrm{~g} \mathrm{dm}^{-3}$ photocatalyst dosage. The value determined for SMP TiO $2 / \mathrm{LED}_{398 \mathrm{~nm}}$ is about 16 times higher than for $\mathrm{SMT} \mathrm{TiO}_{2} / \mathrm{LED}_{398 \mathrm{~nm}}$, while for other cases $\left(\mathrm{TiO}_{2} / \mathrm{LED}_{365 \mathrm{~nm}}, \mathrm{TiO}_{2} / \mathrm{LED}_{365 \mathrm{~nm}}, \mathrm{TiO}_{2} / \mathrm{LED}_{365 \mathrm{~nm}}\right)$, similar or even lower values were observed for SMP than SMT.
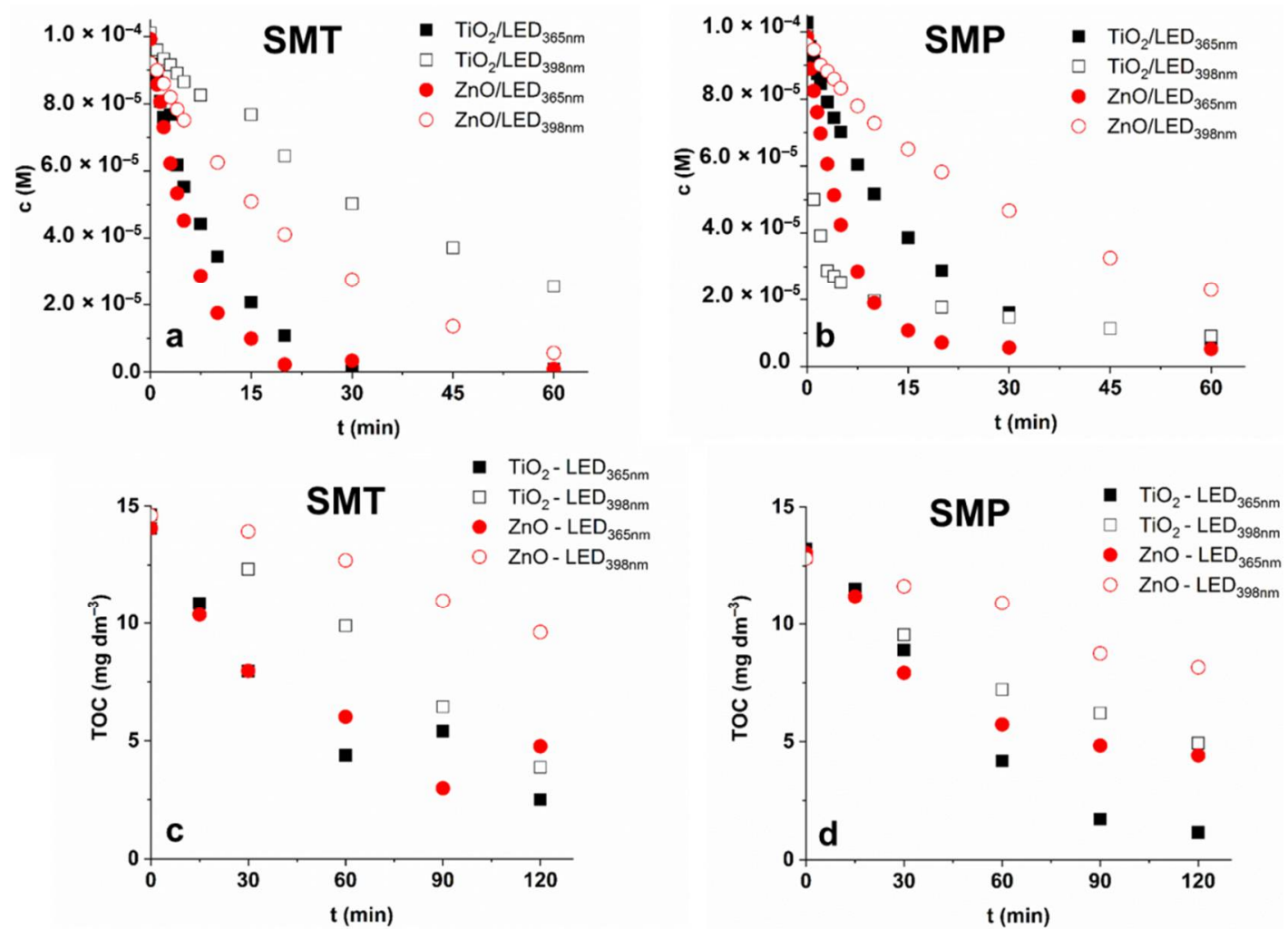

Figure 4. The concentration and TOC content of SMT $(\mathbf{a}, \mathbf{c})$ and SMP $(\mathbf{b}, \mathbf{d})$ during treatments.

Table 1. The initial transformation rates of SMT and SMP and the apparent quantum efficiencies $(\Phi)$ of the related processes.

\begin{tabular}{|c|c|c|c|c|c|c|c|c|}
\hline & \multicolumn{4}{|c|}{$\mathrm{TiO}_{2}$} & \multicolumn{4}{|c|}{$\mathrm{ZnO}$} \\
\hline & \multicolumn{2}{|c|}{ SMT } & \multicolumn{2}{|c|}{ SMP } & \multicolumn{2}{|c|}{ SMT } & \multicolumn{2}{|c|}{ SMP } \\
\hline & $\begin{array}{c}\mathrm{r}_{0} \mathrm{SMT} \\
\left(\mathrm{mol} \mathrm{dm} \mathrm{dm}^{-3} \mathrm{~s}^{-1}\right)\end{array}$ & $\Phi^{\mathrm{SMT}}$ & $\begin{array}{c}\mathrm{r}_{0} \mathrm{SMP} \\
\left(\mathrm{mol} \mathrm{dm} \mathrm{dm}^{-3} \mathrm{~s}^{-1}\right)\end{array}$ & $\Phi^{\mathrm{SMP}}$ & $\begin{array}{c}\mathrm{r}_{0} \text { SMT } \\
\left(\mathrm{mol} \mathrm{dm}^{-3} \mathrm{~s}^{-1}\right)\end{array}$ & $\Phi^{\mathrm{SMT}}$ & $\begin{array}{c}\mathrm{r}_{0} \mathrm{SMP} \\
\left(\mathrm{mol} \mathrm{dm} \mathrm{dm}^{-3} \mathrm{~s}^{-1}\right)\end{array}$ & $\Phi^{\mathrm{SMP}}$ \\
\hline $\mathrm{LED}_{365 \mathrm{~nm}}$ & $1.93 \times 10^{-7}$ & $7.0 \times 10^{-3}$ & $1.68 \times 10^{-7}$ & $6.1 \times 10^{-3}$ & $2.08 \times 10^{-7}$ & $7.6 \times 10^{-3}$ & $2.35 \times 10^{-7}$ & $8.5 \times 10^{-3}$ \\
\hline $\mathrm{LED}_{398 \mathrm{~nm}}$ & $4.53 \times 10^{-8}$ & $9.7 \times 10^{-4}$ & $7.38 \times 10^{-7}$ & $1.6 \times 10^{-2}$ & $6.43 \times 10^{-8}$ & $1.4 \times 10^{-3}$ & $4.12 \times 10^{-8}$ & $8.8 \times 10^{-4}$ \\
\hline
\end{tabular}

To interpret the specific behavior of SMP, we first examined and compared the distribution of aromatic intermediates, which are formed and transformed during the first $60 \mathrm{~min}$. of treatment. The proposed structures of the formed products of SMT and SMP are summarized in Figure 5, while product distribution is shown in Figures S2 and S3. For SMT, six stable products were observed on the chromatogram (HPLC-DAD) (Figure S2), and four of them were identified with MS. The SM/3 product $(m / z=293.2)$ resulted by the oxidation of the terminal amino group, while SM/4 $(m / z=311.0), \mathrm{SM} / 5$, and SM/6 $(m / z=295.1)$ formed via hydroxylation of the aromatic ring, most probably due to the reaction with • $\mathrm{OH}[75,76]$. No significant difference was found between the products formed using $\mathrm{TiO}_{2}$ and $\mathrm{ZnO}$; however, $\mathrm{ZnO}$ produced a higher SM/5 concentration (Figure S2). The distribution of the products does not depend on the wavelength; only their accumulation and decomposition rate was higher using $\mathrm{LED}_{365 \mathrm{~nm}}$ than $\mathrm{LED}_{398 \mathrm{~nm}}$. 


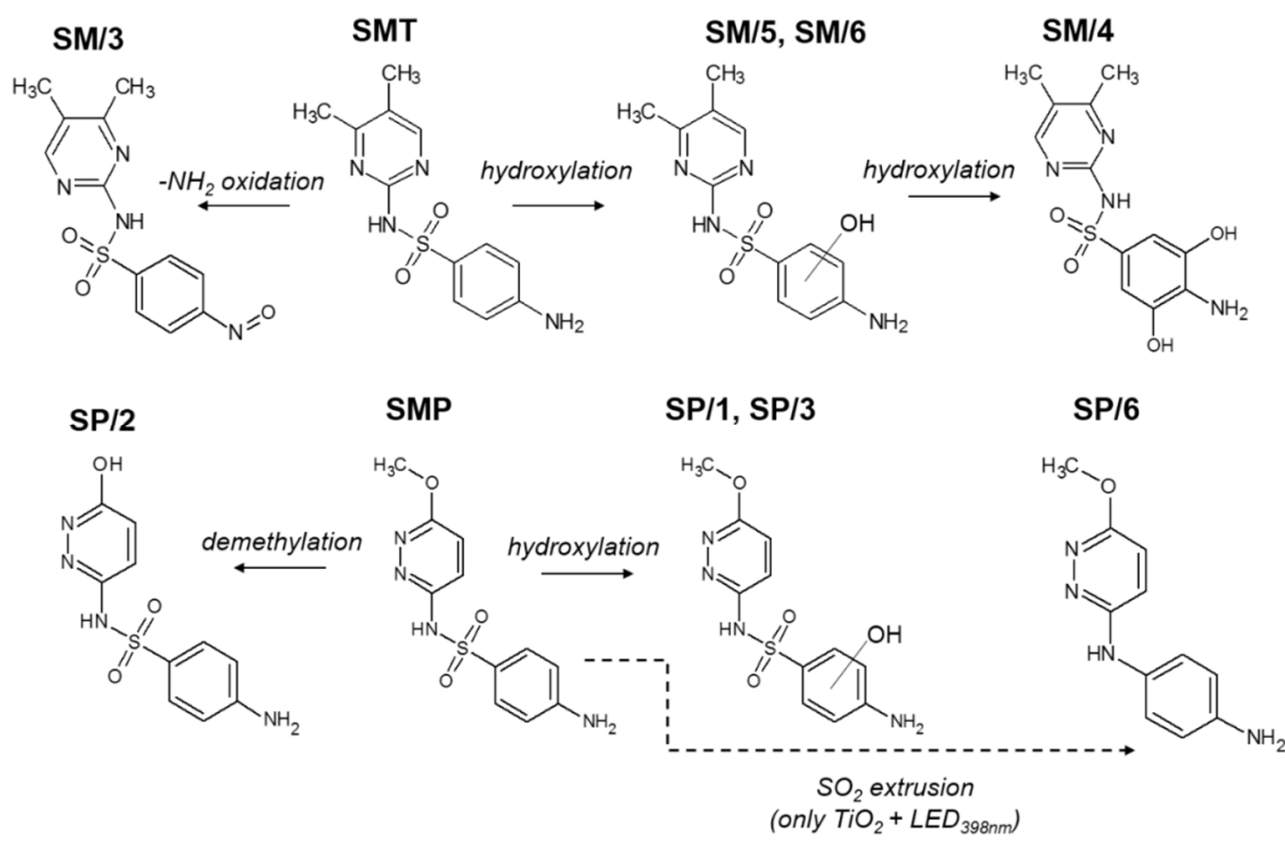

Figure 5. The proposed primary stable products of SMT and SMP transformation during heterogeneous photocatalysis.

In the case of SMP, SP/1 and SP/3 are hydroxylated products $(m / z=297.1)$, while $\mathrm{SP} / 2(m / z=267.0)$ is resulted by demethylation [77]. The same products formed with a similar concentration distribution for $\mathrm{ZnO}$ using different LEDs. For SMT, the product distribution was similar for $\mathrm{TiO}_{2}$ and $\mathrm{ZnO}$, while for SMP, it was different; SP/1 and SP/2 formed mainly in the case of $\mathrm{ZnO}$, and SP/4 was observed only for $\mathrm{TiO}_{2}$ using $\mathrm{LED}_{365 \mathrm{~nm}}$. (Figure S3). However, in the case of $\mathrm{TiO}_{2} / \mathrm{LED}_{398 \mathrm{~nm}}$, not only did the conversion rate of SMP increase drastically but also the intermediates were changed in the case of lowerenergy $398 \mathrm{~nm}$ radiation: besides the main product SP / $6(\mathrm{~m} / z=217.0)$, which forms via $-\mathrm{SO}_{2}$-extrusion, the formation of hydroxylated products is negligible. The significant change of the primary products in the case of $\mathrm{TiO}_{2} / \mathrm{LED}_{398 \mathrm{~nm}}$ process indicates that the reaction mechanism of SMP is different in this case.

The primary product of sulfonamides often forms via desulfonation in both direct and indirect photodegradation processes [78-80]. Boreen et al. attributed the indirect oxidation partly to the interaction with triplet excited-state dissolved organic matters when the $-\mathrm{SO}_{2}$ - extrusion happens due to the electron transfer and not to the energy transfer. The $-\mathrm{SO}_{2}$ - extrusion as the primary transformation way was also reported in a previous work of the authors; the reaction happened selectively, $\mathrm{BiOI} / \mathrm{BiOCl}$ photocatalysts [51] and direct charge transfer was supposed as the primary transformation process. Ge et al. compared the major conversion pathways for the transformation of different sulfonamides initiated by photolysis, ${ }^{\bullet} \mathrm{OH}$-based, and singlet oxygen and desulfonation was particularly characteristic of photolysis, which includes direct photolysis and photosensitization via triplet excited-state dissolved organic matters [81]. All of these suggest that besides ${ }^{\bullet} \mathrm{OH}$ and direct charge transfer, the relative contribution of the reaction with singlet oxygen and direct energy transfer cannot be ignored and, despite their selectivity, can significantly contribute to the conversion of individual sulfonamides.

\subsection{Mineralization of Sulfonamides and Ecotoxicity Assays}

In the case of ozonation and UV photolysis, the intermediates of sulfonamides often have toxic effects. Moreover, chemicals together produce combination effects that are larger than the effects of the component separately. Thus, the change of ecotoxicity of the treated solution was investigated using Vibrio fischeri as a test organism. The $1.0 \times 10^{-4} \mathrm{M}$ concentration SMT and SMP caused a relatively low $(<20 \%)$ inhibition. For SMT, the toxicity 
did not change or even increased slightly due to the formation of toxic products, then slowly decreased as their further transformation progressed (Figure 6a). For SMP, more significant changes were observed; it increased intensively and later decreased, and finally, toxicity lowered below the parent compound in the case of $\mathrm{LED}_{365 \mathrm{~nm}}$ (Figure 6b). The ecotoxicity change in the case of $\mathrm{LED}_{398 \mathrm{~nm}}$ depends on the photocatalysts: for SMT, the ZnO, while for $\mathrm{SMP}$, the $\mathrm{TiO}_{2}$ is the more efficient.
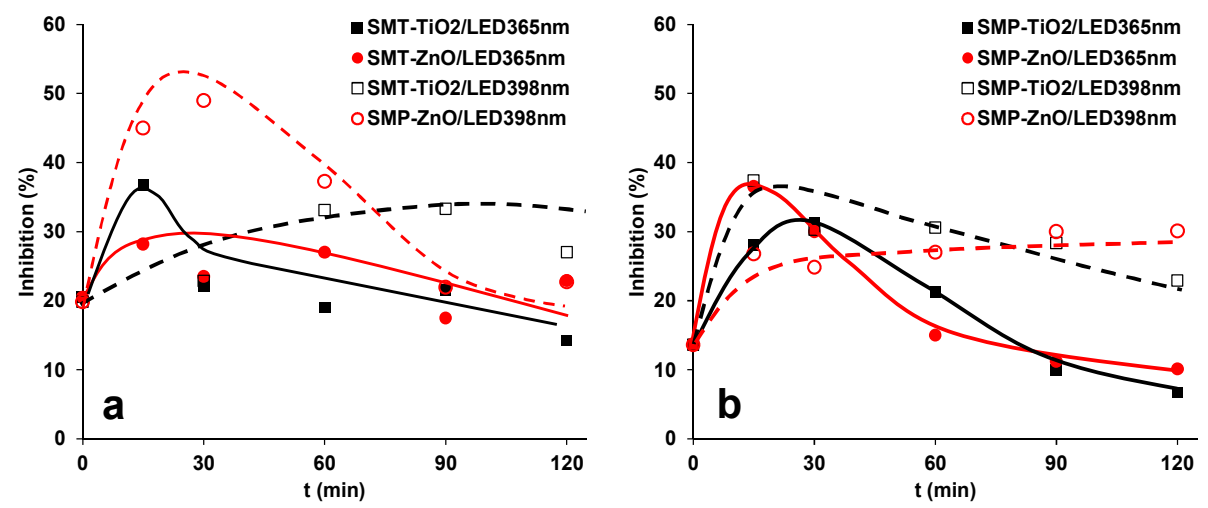

Figure 6. Change of ecotoxicity of the SMT (a) and SMP (b) solutions as a function of treatment time.

The main goal of AOPs is generally not only the transformation but the complete mineralization of pollutants to avoid the accumulation of potentially toxic intermediates. In the case of SMT, both $\mathrm{TiO}_{2}$ and $\mathrm{ZnO}$ irradiated with $\mathrm{LED}_{365 \mathrm{~nm}}$ reduced the TOC by $\sim 80 \%$. Using $\mathrm{LED}_{398 \mathrm{~nm}}$, the $\mathrm{ZnO}$ is more efficient for SMT transformation than $\mathrm{TiO}_{2}$, but mineralization is two times faster with $\mathrm{TiO}_{2}$ and finally (at $120 \mathrm{~min}$ ) approaches the value measured in the case of $\mathrm{LED}_{365 \mathrm{~nm}}$, while using $\mathrm{ZnO} / \mathrm{LED}_{398 \mathrm{~nm}}$ no more than $33 \%$ TOC was removed (Figure $4 \mathrm{c}, \mathrm{d}$ ).

For SMP, $\mathrm{TiO}_{2}$ is more efficient (90 and 62\% decrease for $\mathrm{LED}_{365 \mathrm{~nm}}$ and $\mathrm{LED}_{398 \mathrm{~nm}}$, respectively) than $\mathrm{ZnO}\left(66 \%\right.$ and $35 \%$ decrease for $\mathrm{LED}_{365 \mathrm{~nm}}$ and $\mathrm{LED}_{398 \mathrm{~nm}}$, respectively) for TOC decrease in the case of both LEDs (Figure 4c,d), despite that, the SMP transformation rate for $\mathrm{ZnO} / \mathrm{LED}_{365 \mathrm{~nm}}$ exceeds that for $\mathrm{TiO}_{2} / \mathrm{LED}_{365 \mathrm{~nm}}$ (Figure 3b, Table 1). Using $\mathrm{TiO}_{2} / \mathrm{LED}_{398 \mathrm{~nm}}$, not only the transformation rate of SMP was extremely fast (Table 1), but also the mineralization was favorable, especially during the first period of treatment, and finally reached the value measured for $\mathrm{ZnO} / \mathrm{LED}_{365 \mathrm{~nm}}$. A plausible explanation of this could be that changes in the mechanism result in more easily oxidizable intermediates and, consequently, increase the mineralization rate. Comparing the mineralization rates, the efficiency change in the same order for both sulfonamides; and $\mathrm{TiO}_{2}$ shows better mineralization capacity than $\mathrm{ZnO}$. The difference is much better manifested for $\mathrm{LED}_{398 \mathrm{~nm}}$ than $\mathrm{LED}_{365 \mathrm{~nm}}$. It confirms that the ${ }^{\bullet} \mathrm{OH}$ is the most important reactive species in terms of mineralization.

For SMT, the formation of inorganic ions $\left(\mathrm{NH}_{4}{ }^{+}, \mathrm{NO}_{3}{ }^{-}, \mathrm{NO}_{2}{ }^{-}\right.$and $\left.\mathrm{SO}_{4}{ }^{2-}\right)$ followed the mineralization efficiency: for $\mathrm{LED}_{365 \mathrm{~nm}}$, similar results were obtained with both catalysts, with a slightly faster $\mathrm{SO}_{4}{ }^{2-}$ formation rate for $\mathrm{ZnO}$ and an enhanced $\mathrm{NH}_{4}{ }^{+}$production for $\mathrm{TiO}_{2}$ (Figures S4 and S5). In the case of $\mathrm{LED}_{365 \mathrm{~nm}}, 85 \%$ of S-content was detected as $\mathrm{SO}_{4}{ }^{2-}$; lower values ( $44 \%$ for $\mathrm{TiO}_{2}$ and $65 \%$ for $\mathrm{ZnO}$ ) were measured for $\mathrm{LED}_{398 \mathrm{~nm}}$. For $\mathrm{LED}_{365 \mathrm{~nm}}$ there was no significant difference between SMT and SMP in terms of inorganic ion formation rate, but it is worth comparing the $\mathrm{SO}_{4}{ }^{2-}$ conversion of SMT and SMP when $\mathrm{TiO}_{2} / \mathrm{LED}_{398 \mathrm{~nm}}$ is used. The $\mathrm{SO}_{4}{ }^{2-}$ conversion for SMT at $15 \mathrm{~min}$ is negligible, and no more than $25 \%$ at $60 \mathrm{~min}$, while these values are $20 \%$ and $50 \%$ for SMP, confirming the different conversion mechanisms of the two sulfonamides and the importance of desulfonation for SMP, as the first step of transformation. (Figure S5). The $\mathrm{SO}_{4}{ }^{2-}$-formation rate for $\mathrm{TiO}_{2} / \mathrm{LED}_{398 \mathrm{~nm}}$, when $-\mathrm{SO}_{2}$-extrusion is supposed to be the dominant transformation pathway, is similar to $\mathrm{TiO}_{2} / \mathrm{LED}_{365 \mathrm{~nm}}$ and even faster for $\mathrm{ZnO} / \mathrm{LED}_{365 \mathrm{~nm}}$ (Figure S5). It proves that desulfonation is an important step not only for $\mathrm{TiO}_{2} / \mathrm{LED}_{398 \mathrm{~nm}}$; it can prob- 
ably occur directly from the target substances as the first step of the transformation and from the aromatic intermediates.

No more than $30 \%$ of the nitrogen content was transformed into $\mathrm{NH}_{4}{ }^{+}$, the $\mathrm{NO}_{3}{ }^{-}$ conversion was even lower $(<14 \%)$ (Figures S4 and S5). For both sulfonamides, $\mathrm{NO}_{2}^{-}$ formation $(<6 \%)$ was observed only for $\mathrm{ZnO}$, which likely forms via the reduction of $\mathrm{NO}_{3}{ }^{-}$ by $\mathrm{e}_{\mathrm{CB}}{ }^{-}$, and not favored on $\mathrm{TiO}_{2}$ surface [82]. $\mathrm{NO}_{2}{ }^{-}$could be easily oxidized with ${ }^{\bullet} \mathrm{OH}$ to $\mathrm{NO}_{3}{ }^{-}\left(\mathrm{k}_{\mathrm{NO} 2-+\bullet \mathrm{OH}}=6.0 \times 10^{9} \mathrm{M}^{-1} \mathrm{~s}^{-1}\right.$ [83]), thus its concentration remains low.

To understand the reason for the unique behavior of the SMP, we have investigated the effect of wavelength and photocatalyst on the ${ }^{\bullet} \mathrm{OH}$ formation rate and charge separation efficiency, using COU and 1,4-BQ.

\subsection{Transformation of Coumarin-The Comparison of $\bullet$ OH Formation Efficiency}

The reaction of $\mathrm{COU}$ with ${ }^{\bullet} \mathrm{OH}\left(\mathrm{k}_{\mathrm{COU}+\bullet \mathrm{OH}}=6.9 \times 10^{9} \mathrm{M}^{-1} \mathrm{~s}^{-1}\right.$ [84] $)$ results in highly fluorescent 7-hydroxy-coumarin (7-HC) [85,86]; its formation rate is proportional to the ${ }^{\bullet} \mathrm{OH}$ formation rate. The ratio of $\mathrm{COU}$ transformation rate and $7-\mathrm{HC}$ formation rate provides further information about the contribution of ${ }^{\bullet} \mathrm{OH}$ to the COU transformation $[85,87,88]$.

The COU adsorption was negligible for both photocatalysts $(<1.0 \%)$, similar to sulfonamides. The effect of the catalyst dose was determined in previous measurements; the $\mathrm{r}_{0} \mathrm{COU}$ reached a maximum value at $1.0 \mathrm{~g} \mathrm{dm}^{-3}$ in the case of both photocatalysts. In this work, the initial concentration of COU was $1.0 \times 10^{-4} \mathrm{M}$, and the catalyst dosage was $1.0 \mathrm{~g} \mathrm{dm}^{-3}$.

The transformation of $\mathrm{COU}$ was slightly faster for $\mathrm{ZnO}$, especially in the case of $\mathrm{LED}_{398 \mathrm{~nm}}$, while the formation rate of 7-HC was significantly higher for $\mathrm{TiO}_{2}$, than for $\mathrm{ZnO}$ in both cases (Table 2). The maximum concentration of this hydroxylated product is almost twice for $\mathrm{TiO}_{2}$ than for $\mathrm{ZnO}$ in the case of $\mathrm{LED}_{365 \mathrm{~nm}}$ and more than three times higher in the case of $\mathrm{LED}_{398 \mathrm{~nm}}$ (Figure $\left.7 \mathrm{a}, \mathrm{b}\right)$. The $\mathrm{r}_{0} \mathrm{COU} / \mathrm{r}_{0}{ }^{7-\mathrm{HC}}$ ratio for $\mathrm{TiO}_{2}(0.027$ and 0.041 for $\mathrm{LED}_{365 \mathrm{~nm}}$ and $\mathrm{LED}_{398 \mathrm{~nm}}$, respectively) also exceeds the value determined for $\mathrm{ZnO}(0.019$ and 0.025 for $\mathrm{LED}_{365 \mathrm{~nm}}$ and $\mathrm{LED}_{398 \mathrm{~nm}}$, respectively). These prove the higher contribution of - $\mathrm{OH}$ to the transformation when $\mathrm{TiO}_{2}$ is used, mainly when $\mathrm{LED}_{398 \mathrm{~nm}}$ is applied (Table 2). Most probably, for $\mathrm{ZnO}$ the transformation of $\mathrm{COU}$ via direct charge transfer processes is favorable due to the higher electron mobility of photogenerated charges [89,90].

Table 2. The initial transformation rates of target substances $\left(\mathrm{r}_{0} \mathrm{COU}\right.$ and $\left.\mathrm{r}_{0}{ }^{1,4-\mathrm{BQ}}\right)$, the initial formation rate of their primary products $\left(\mathrm{r}_{0}{ }^{7-\mathrm{HC}}\right.$ and $\left.\mathrm{r}_{0}{ }^{1,4-\mathrm{H} 2 \mathrm{Q}}\right)$, and the apparent quantum efficiency $(\Phi)$ of the related processes.

\begin{tabular}{|c|c|c|c|c|c|c|c|c|}
\hline & \multicolumn{4}{|c|}{$\mathrm{TiO}_{2}$} & \multicolumn{4}{|c|}{$\mathrm{ZnO}$} \\
\hline & \multicolumn{8}{|c|}{$\mathrm{COU} \rightarrow 7-\mathrm{HC}$} \\
\hline & $\begin{array}{c}\mathrm{r}_{0} \mathrm{COU} \\
\left(\mathrm{mol} \mathrm{dm} \mathrm{dm}^{-3} \mathrm{~s}^{-1}\right)\end{array}$ & $\Phi^{\mathrm{COU}}$ & $\begin{array}{c}\mathrm{r}_{0}{ }^{7-\mathrm{HC}} \\
\left(\mathrm{mol} \mathrm{dm}^{-3} \mathrm{~s}^{-1}\right)\end{array}$ & $\Phi^{7-\mathrm{HC}}$ & $\begin{array}{c}\mathrm{r}_{0} \mathrm{COU} \\
\left(\mathrm{mol} \mathrm{dm} \mathrm{dm}^{-3} \mathrm{~s}^{-1}\right)\end{array}$ & $\Phi^{\mathrm{COU}}$ & $\begin{array}{c}\mathrm{r}_{0}{ }^{7-\mathrm{HC}} \\
\left(\mathrm{mol} \mathrm{dm}^{-3} \mathrm{~s}^{-1}\right)\end{array}$ & $\Phi^{7-\mathrm{HC}}$ \\
\hline $\mathrm{LED}_{365 \mathrm{~nm}}$ & $1.53 \times 10^{-7}$ & $5.5 \times 10^{-3}$ & $4.1 \times 10^{-9}$ & $1.5 \times 10^{-4}$ & $1.54 \times 10^{-7}$ & $3.2 \times 10^{-3}$ & $2.88 \times 10^{-9}$ & $0.6 \times 10^{-4}$ \\
\hline \multirow[t]{3}{*}{$\mathrm{LED}_{398 \mathrm{~nm}}$} & $3.80 \times 10^{-8}$ & $0.8 \times 10^{-3}$ & $1.5 \times 10^{-9}$ & $0.3 \times 10^{-4}$ & $5.18 \times 10^{-8}$ & $1.1 \times 10^{-3}$ & $1.29 \times 10^{-9}$ & $0.3 \times 10^{-4}$ \\
\hline & \multicolumn{8}{|c|}{$1,4-\mathrm{BQ} \rightarrow 1,4-\mathrm{H}_{2} \mathrm{Q}$} \\
\hline & $\begin{array}{c}\mathrm{r}_{0}{ }^{\mathrm{BQ}} \\
\left(\mathrm{mol} \mathrm{dm} \mathrm{dm}^{-3} \mathrm{~s}^{-1}\right)\end{array}$ & $\Phi^{1,4-\mathrm{BQ}}$ & $\begin{array}{c}\mathrm{r}_{0}^{1,4-\mathrm{H}_{2} \mathrm{Q}} \\
\left(\mathrm{mol} \mathrm{dm}^{-3} \mathrm{~s}^{-1}\right)\end{array}$ & $\Phi^{1,4-\mathrm{H}_{2} \mathrm{Q}}$ & $\begin{array}{c}\mathrm{r}_{0}{ }^{\mathrm{BQ}} \\
\left(\mathrm{mol} \mathrm{dm} \mathrm{dm}^{-3} \mathrm{~s}^{-1}\right)\end{array}$ & $\Phi^{1,4-\mathrm{BQ}}$ & $\begin{array}{c}\mathrm{r}_{0}^{1,4-\mathrm{H}_{2} \mathrm{Q}} \\
\left(\mathrm{mol} \mathrm{dm}^{-3} \mathrm{~s}^{-1}\right)\end{array}$ & $\Phi^{1,4-\mathrm{H}_{2} \mathrm{Q}}$ \\
\hline $\mathrm{LED}_{365 \mathrm{~nm}}$ & $2.78 \times 10^{-6}$ & $1.0 \times 10^{-1}$ & $2.61 \times 10^{-6}$ & $9.5 \times 10^{-2}$ & $3.12 \times 10^{-6}$ & $1.1 \times 10^{-1}$ & $2.47 \times 10^{-6}$ & $8.9 \times 10^{-2}$ \\
\hline $\mathrm{LED}_{398 \mathrm{~nm}}$ & $8.88 \times 10^{-7}$ & $1.9 \times 10^{-2}$ & $7.61 \times 10^{-7}$ & $1.5 \times 10^{-2}$ & $1.19 \times 10^{-6}$ & $2.6 \times 10^{-2}$ & $8.07 \times 10^{-7}$ & $1.7 \times 10^{-2}$ \\
\hline
\end{tabular}

The apparent quantum yield $\left(\Phi^{\mathrm{COU}}\right)$ relates to the COU transformation is higher for $\mathrm{TiO}_{2}$ than for $\mathrm{ZnO}$ (Table 2); opposite that, the light absorption properties of $\mathrm{ZnO}$ are more favorable at $365 \mathrm{~nm}$ (Figure 1b). When $\mathrm{LED}_{398 \mathrm{~nm}}$ is used, primarily the rutile phase can be excited due to its lower bandgap. Since the rutile content of $\mathrm{TiO}_{2}$ is only $15 \%$, the $\Phi^{\mathrm{COU}}$ is significantly lower at this wavelength than for $\mathrm{ZnO}$ (Table 2). Comparing the $\Phi^{\mathrm{COU}}$ value determined at two different wavelengths was 7 times higher for $\mathrm{TiO}_{2}$, but only 3 times higher for $\mathrm{ZnO}$ at $365 \mathrm{~nm}$ than $398 \mathrm{~nm}$. Similar ratios can be observed for $\Phi^{7-\mathrm{HC}}$ values. 
The different wavelengths and photon flux can affect photogenerated charge carriers' formation and recombination rate [91,92], affecting the quantum efficiency of $\bullet \mathrm{OH}$ formation.
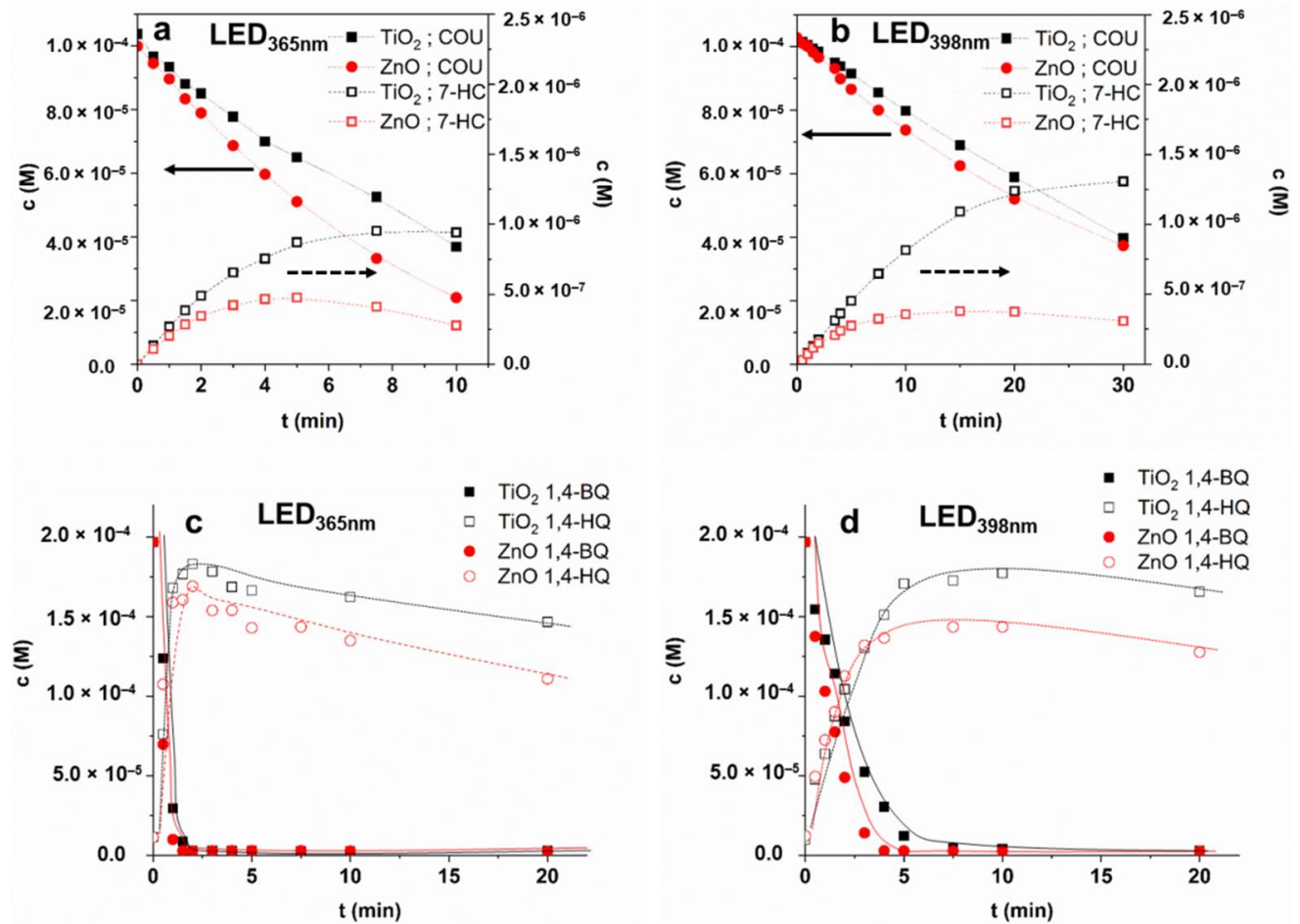

Figure 7. The concentration of COU and 7-HC $(\mathbf{a}, \mathbf{b})$ in aerated suspensions and the concentration of 1,4-BQ and 1,4- $\mathrm{H}_{2} \mathrm{Q}(\mathbf{c}, \mathbf{d})$ in oxygen-free suspensions ((a,c): $\left.\mathrm{LED}_{365 \mathrm{~nm}} ;(\mathbf{b}, \mathbf{d}): \mathrm{LED}_{398 \mathrm{~nm}}\right)$.

The efficiency of both photocatalysts was lower at $398 \mathrm{~nm}$, but despite the nearly $80 \%$ reflection and the wide bandgaps $(3.2 \mathrm{eV})$, pretty good activities were measured compared to the irradiation at $365 \mathrm{~nm}$. It is probably due to the presence of rutile for $\mathrm{TiO}_{2}$ and the heterojunction between the rutile and anatase phases. The results on COU conversion confirmed that ${ }^{\bullet} \mathrm{OH}$ formation is much more efficient for $\mathrm{TiO}_{2}$ than for $\mathrm{ZnO}$, and that wavelength also has a significant effect on ${ }^{\bullet} \mathrm{OH}$ formation efficiency but does not explain the behavior of SMP.

\subsection{Transformation of 1,4-BQ-The Comparison of Charge Separation Efficiency}

Besides ${ }^{\bullet} \mathrm{OH}$ formation efficiency, the possibility of direct charge transfer and efficiency of $\mathrm{e}_{\mathrm{CB}}{ }^{-}$was also studied and compared. Fónagy et al. demonstrated that 1,4-benzoquinone $(1,4-\mathrm{BQ})$ can be used as a direct $\mathrm{e}_{\mathrm{CB}}{ }^{-}$scavenger under anoxic atmosphere, and the amount of the formed 1,4- $\mathrm{H}_{2} \mathrm{Q}$ is proportional to that of $\mathrm{e}_{\mathrm{CB}}{ }^{-}$generated during the excitation of a photocatalyst [93]. Thus, we used the transformation rate of 1,4-benzoquinone (1,4-BQ) and the formation rate of $1,4-\mathrm{H}_{2} \mathrm{Q}$ to investigate and compare the formation rate of photogenerated $\mathrm{e}_{\mathrm{CB}}-$ The backward reaction is also possible; reaction between $1,4-\mathrm{H}_{2} \mathrm{Q}$ and $\mathrm{h}_{\mathrm{VB}}{ }^{+}$ (Equation (2)) results in 1,4-BQ [93,94].

$$
\begin{gathered}
1,4-\mathrm{BQ}+2 \mathrm{e}_{\mathrm{CB}}^{-}+2 \mathrm{H}^{+} \rightarrow 1,4-\mathrm{H}_{2} \mathrm{Q} \\
1,4-\mathrm{H}_{2} \mathrm{Q}+2 \mathrm{~h}_{\mathrm{VB}}^{+} \rightarrow 1,4-\mathrm{BQ}+2 \mathrm{H}^{+} \\
\mathrm{h}_{\mathrm{VB}}{ }^{+}+\mathrm{OH}^{-} / \mathrm{H}_{2} \mathrm{O} \rightarrow \bullet \mathrm{OH} \\
1,4-\mathrm{BQ}+{ }^{\bullet} \mathrm{OH} \rightarrow \text { Products } \\
1,4-\mathrm{H}_{2} \mathrm{Q}+{ }^{\bullet} \mathrm{OH} \rightarrow \text { Products }
\end{gathered}
$$


The transformation rate of $1,4-\mathrm{BQ}$ via direct charge transfer in $\mathrm{O}_{2}$-free suspension highly exceeds that of the COU transformation, mainly based on reactions initiated by - $\mathrm{OH}$ in $\mathrm{O}_{2}$-containing suspension (Table 2). The difference between the efficiency of photocatalysts was observed when $\mathrm{LED}_{398 \mathrm{~nm}}$ was applied; the 1,4-BQ transformation was faster for $\mathrm{ZnO}$ than $\mathrm{TiO}_{2}$ (Figure 7d), most probably due to the higher electron mobility of $\mathrm{ZnO}[89,90]$. The transformation was slower for both $\mathrm{TiO}_{2}$ and $\mathrm{ZnO}$ using $398 \mathrm{~nm}$ light due to intense reflection at this wavelength and generating fewer $\mathrm{e}_{\mathrm{CB}}{ }^{-}-\mathrm{h}_{\mathrm{VB}}{ }^{+}$pairs than $365 \mathrm{~nm}$ photons. In both cases, the maximum concentration of $1,4-\mathrm{H}_{2} \mathrm{Q}$ was higher for $\mathrm{TiO}_{2}$ and just slowly transformed. The 1,4-BQ was present $\left(c>2.3( \pm 0.2) \times 10^{-6} \mathrm{M}\right)$ during the whole treatment time, clearly indicating the backward reaction via $\mathrm{h}_{\mathrm{VB}}{ }^{+}$(Equation (2)). In the absence of $\mathrm{O}_{2}$, the reformed 1,4-BQ (Equation (2)) acts as an $\mathrm{e}_{\mathrm{CB}}{ }^{-}$acceptor (Equation (1)), which opens up the way for ${ }^{\bullet} \mathrm{OH}$ formation (Equation (3)). Most probably, the slow decrease of the sum of 1,4-BQ and 1,4- $\mathrm{H}_{2} \mathrm{Q}$ concentrations is caused by ${ }^{\bullet} \mathrm{OH}$ initiated transformation $\left(\mathrm{k}_{1,4-\mathrm{BQ}} \bullet \mathrm{OH}=1.2 \times 10^{9} \mathrm{M}^{-1} \mathrm{~s}^{-1}\right.$ [95] (Equation (4); $\mathrm{k}_{1,4-\mathrm{H} 2 \mathrm{Q}+\bullet \mathrm{OH}}=5.2 \times 10^{9} \mathrm{M}^{-1} \mathrm{~s}^{-1}$ [96] (Equation (5)) (Figure 7d).

Sulfonamides react fast not only with ${ }^{\bullet} \mathrm{OH}$ but also $\mathrm{e}_{\mathrm{aq}}{ }^{-}$. Mezyk et al. investigated the kinetics and efficiencies of ${ }^{\bullet} \mathrm{OH}$ and $\mathrm{e}_{\mathrm{aq}}{ }^{-}$based reactions to the transformation of four different sulfa drugs (sulfamethazine, sulfamethizole, sulfamethoxazole, and sulfamerazine) [97]. The rate constants of $\bullet \mathrm{OH}$ based oxidation $\left(7.8-8.5 \times 10^{9} \mathrm{M}^{-1} \mathrm{~s}^{-1}\right)$ and degradation efficiencies were similar (changed from 35\% to 53\%). The rate constants of reduction with the $\mathrm{e}_{\mathrm{aq}}{ }^{-}\left(1.0-2.1 \times 10^{10} \mathrm{M}^{-1} \mathrm{~s}^{-1}\right)$ was even higher and varied within small ranges, but the corresponding degradation efficiency resulted in highly different values from $0.5 \%$ to $71 \%$. They proposed that ${ }^{\bullet} \mathrm{OH}$ adds predominantly to the sulfanilic acid ring, while reaction with $\mathrm{e}_{\mathrm{aq}}{ }^{-}$occurs at different reaction sites of the different heterocyclic rings. The higher transformation rate of SMT and SMP, for $\mathrm{ZnO}$ than $\mathrm{TiO}_{2}$ is probably due to their direct reaction with photogenerated charges. Although the significant contribution of direct charge transfer to the conversion is a possible way to explain the difference of transformation rates observed between $\mathrm{TiO}_{2}$ and $\mathrm{ZnO}$, it is difficult to interpret the behavior of SMP in the case of $\mathrm{TiO}_{2} / \mathrm{LED}_{398 \mathrm{~nm}}$ by this way considering that the number of photogenerated charges is much higher for $\mathrm{LED}_{365 \mathrm{~nm}}$.

\subsection{Reaction Mechanism-Effect of Radical Scavenger, Dissolved $\mathrm{O}_{2}$, and the Quality of $\mathrm{TiO}_{2}$}

Sulfonamides react fast with ${ }^{\bullet} \mathrm{OH}\left(\mathrm{k}_{\mathrm{SMT}}+\bullet \mathrm{OH}=8.3 \times 10^{9} \mathrm{M}^{-1} \mathrm{~s}^{-1}\right.$ [97]); thus, the effect of methanol $(\mathrm{MeOH})$ as $\bullet \mathrm{OH}$-scavenger $\left(\mathrm{k}_{\mathrm{MeOH}+\bullet \mathrm{OH}}=9.7 \times 10^{8} \mathrm{M}^{-1} \mathrm{~s}^{-1}\right.$ [98] $)$ was investigated. The addition of $2.5 \times 10^{-3} \mathrm{M} \mathrm{MeOH}$ to $1.0 \times 10^{-4} \mathrm{M}$ SMT or SMP scavenges more than $70 \%$ of ${ }^{\bullet} \mathrm{OH}$ reduced the transformation rates to about half in each case (Figure 8) for $\mathrm{TiO}_{2} / \mathrm{LED}_{398 \mathrm{~nm}}$, the SMP transformation was decreased to a similar value than $\mathrm{TiO}_{2} / \mathrm{LED}_{365 \mathrm{~nm}}$ or $\mathrm{ZnO} / \mathrm{LED}_{365 \mathrm{~nm}}$. MeOH can also be used as a $\mathrm{h}_{\mathrm{VB}}{ }^{+} \mathrm{scav}-$ enger $[82,99,100]$; therefore, it might prevent the direct oxidation of SMP, but this is not a likely explanation in this case. The direct energy transfer is supposed to be the main reason for the photocatalytic isomerization of trans-caffeic acid in $\mathrm{TiO}_{2}$ suspension [26] The addition of $\mathrm{MeOH}$ completely inhibited the transformation in that case; the effect was much larger than expected based on the radical scavenging capacity of $\mathrm{MeOH}$, similar to its effect on SMP transformation for $\mathrm{TiO}_{2} / \mathrm{LED}_{398 \mathrm{~nm}}$.

Both energy transfer and direct charge transfer could increase the conversion rate, change the reaction pathway, and alter the quality of the primary intermediate. The unique behavior of SMP for $\mathrm{TiO}_{2} / \mathrm{LED}_{398 \mathrm{~nm}}$ needed further investigation to clarify since the effect of $\mathrm{MeOH}$ was not enough for its proper interpretation, although its high impact indirectly confirmed the role of direct energy transfer.

In $\mathrm{O}_{2}$ containing suspension, $\mathrm{e}_{\mathrm{CB}}{ }^{-}$reacts with molecular $\mathrm{O}_{2}$, which is a source of the ROS formation. The further transformation of $\mathrm{O}_{2}{ }^{\bullet-}$ creates a possibility to the ${ }^{\bullet} \mathrm{OH}-$ formation via $\mathrm{H}_{2} \mathrm{O}_{2}$, while in $\mathrm{O}_{2}$-free suspension ${ }^{\bullet} \mathrm{OH}$ formation is limited to the reaction of $\mathrm{H}_{2} \mathrm{O} / \mathrm{OH}^{-}$with $\mathrm{h}_{\mathrm{VB}}{ }^{+}$. In the $\mathrm{O}_{2}$-free suspension, the initial conversion of SMP is slower but still very significant, especially since most organic compounds are not converted at 
all without $\mathrm{O}_{2}$. The shape of the kinetic curves is similar in both $\mathrm{O}_{2}$-free and aerated suspension: after $45 \%$ and $75 \%$ removal of SMP, its further transformation became very slow, almost negligible (Figure 9). In both cases, the main intermediate forms via desulfonation, the concentration of hydroxylated products is negligible. The transformation in $\mathrm{O}_{2}$-free suspension via direct charge transfer can take place if SMP could behave as $\mathrm{e}_{\mathrm{CB}}{ }^{-}$scavenger instead of $\mathrm{O}_{2}$, and both oxidation and reduction of SMP can happen similar to the double electron transfer suggested for the formation of singlet oxygen by Nosaka et al. [21]. Thus, two processes are possible: one is the oxidation and reduction of SMP taking place parallel when different parts of the molecule react with $\mathrm{e}_{\mathrm{CB}}{ }^{-}$and $\mathrm{h}_{\mathrm{VB}}{ }^{+}$or the direct energy transfer, when excited photocatalysts particles transfer energy to SMP, which is finally transformed. If the reaction with ROS or direct charge transfer process is primarily responsible for transforming an organic compound, its conversion is generally negligible in $\mathrm{O}_{2}$-free suspension. However, the rapid desulfonation of SMP in an $\mathrm{O}_{2}$-free suspension confirms that the energy transfer is primarily responsible for its conversion. Of course, the contribution of the reactions with the formed ROS in the presence of $\mathrm{O}_{2}$ are not negligible.
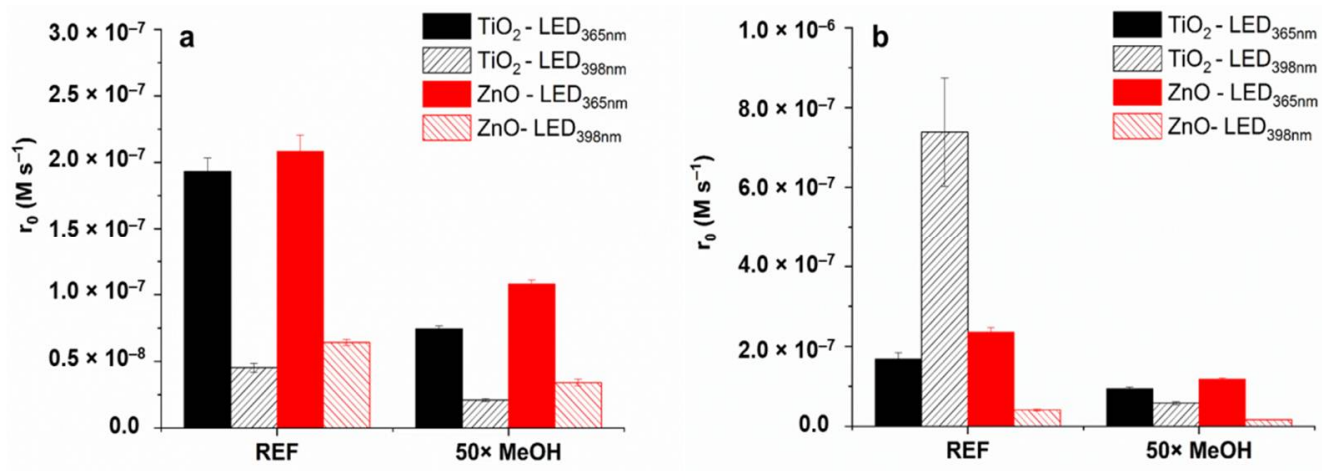

Figure 8. The effect of $2.5 \times 10^{-3} \mathrm{M} \mathrm{MeOH}$ on the initial transformation rate of SMT (a) and SMP (b).

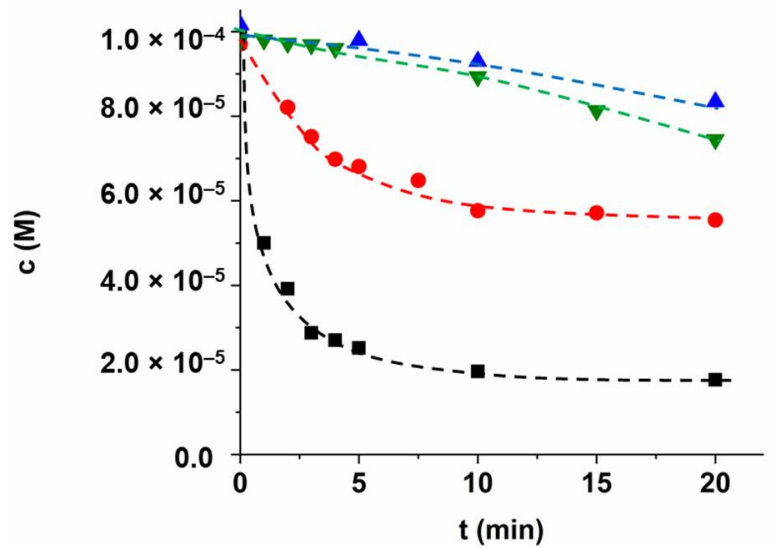

- $\mathrm{TiO}_{2} \mathrm{P} 25 / \mathrm{O}_{2}$

- $\mathrm{TiO}_{2} \mathrm{P} 25 / \mathrm{N}_{2}$

- Anatase $/ \mathrm{O}_{2}$

- Rutile/ $\mathrm{O}_{2}$

Figure 9. The concentration of SMP in aerated and $\mathrm{O}_{2}$-free suspensions using different $\mathrm{TiO}_{2}$ photocatalysts and $\mathrm{LED}_{398 \mathrm{~nm}}$.

After 5 and $10 \mathrm{~min}$, there is a "breaking point" on the kinetic curves; after that, the SMP transformation is inhibited, especially in $\mathrm{O}_{2}$ containing suspension. The energy transfer can take place via a different mechanism. In the case of "trivial energy transfer", SMP absorbs the photon emitted by the excited semiconductor. Unlike the trivial mechanism, Förster and Dexter energy transfers are radiationless processes and strongly depend on the distance of the acceptor from the semiconductor. No electron exchange between acceptor and donor occurs when Förster mechanism takes place, while Dexter energy transfer mechanism occurs when simultaneously two electrons move in opposite directions without net charge exchange. The formed $\mathrm{SO}_{3}{ }^{2-} / \mathrm{SO}_{4}{ }^{2-}$ species and other ions and organic intermediates can adsorb on the $\mathrm{TiO}_{2}$ surface [101]. The change of catalysts surface can impede the 
access to the surface and thus energy transfer via Förster or Dexter mechanism. Moreover, the poisoning of the catalyst surface can also reduce efficiency [102].

The synergistic effect between the two crystal phases resulting in enhanced charge separation and photocatalytic activity was proved by several authors [32,33,103]. Under $398 \mathrm{~nm}$ irradiation, mainly the rutile phase excited (Figure $1 b$ ), the photogenerated $\mathrm{e}_{\mathrm{CB}}{ }^{-} \mathrm{can}$ migrate to the anatase phase, inhibiting the recombination of photogenerated charges [104]. Although heterojunction is controversial, the great activity of P25 is undoubted. For determining whether the unique behavior of the SMP is manifested in the case of anatase or rutile phase or characteristic only to the P25, we examined the conversion of SMP in the presence of pure anatase and rutile phase. But only a slow transformation occurred (Figure 9). The intensive desulfonation was not observed. Mainly hydroxylated products formed indicating a ${ }^{\bullet} \mathrm{OH}$ based reaction pathway in the case of anatase and rutile.

From this, it can be concluded that the unique transformation of SMP is only possible for $\mathrm{TiO}_{2} \mathrm{P} 25$ and is most likely a consequence of the energy transfer, which takes place in this particular case, using P25 photocatalyst and $398 \mathrm{~nm}$ radiation. However, the role of direct charge transfer cannot be excluded, and in $\mathrm{O}_{2}$-containing suspensions, the ${ }^{\bullet} \mathrm{OH}$-based reaction is likely to contribute to the transformation and mineralization of the products.

\subsection{Effect of Matrices on the Removal of Sulfonamides}

Experiments were performed with SMT and SMP in two water matrices: tapwater with a low organic and high inorganic content, and biologically treated and filtered domestic wastewater (BTWW) with higher organic and inorganic content (Table S2). For investigation of the inorganic components' effect, transformation rates were determined in suspensions containing the two most abundant anions, $\mathrm{Cl}^{-}\left(120 \mathrm{mg} \mathrm{dm}{ }^{-3}\right)$ and $\mathrm{HCO}_{3}{ }^{-}\left(525 \mathrm{mg} \mathrm{dm}^{-3}\right)$. The concentration of the anions was set to the values measured in the biologically treated wastewater (Table S2).

For SMT, the inhibition effect of matrices was negligible when $\mathrm{ZnO}$ photocatalyst was applied, while for $\mathrm{TiO}_{2}$ decreased by 25 and $50 \%$ using $\mathrm{LED}_{365 \mathrm{~nm}}$ and $\mathrm{LED}_{398 \mathrm{~nm}}$, respectively (Figure 10a,b). The negative effect of $\mathrm{HCO}_{3}{ }^{-}$was more pronounced for $\mathrm{ZnO}$ (decrease by $34 \%$ ) than $\mathrm{TiO}_{2}$, while the effect of $\mathrm{Cl}^{-}$is not significant (Figure 10a). A more enhanced inhibition by the matrices was observed in the case of $\mathrm{LED}_{398 \mathrm{~nm}}$. For SMP, similar observations can be made, except $\mathrm{TiO}_{2} / \mathrm{LED}_{398 \mathrm{~nm}}$, when both matrices and $\mathrm{HCO}_{3}{ }^{-}$ inhibited the SMP transformation completely (Figure 10b,d). Even $\mathrm{Cl}^{-}$is inhibited the conversion, while it had no effect in other cases (Figure 10d).

$\mathrm{HCO}_{3}{ }^{-}$is a well-known ${ }^{-} \mathrm{OH}$ scavenger, but its reaction rate constant is relatively low $\left(\mathrm{k}_{\mathrm{HCO}_{3}{ }^{-}+{ }^{\bullet} \mathrm{OH}}=1.0 \times 10^{-7} \mathrm{M}^{-1} \mathrm{~s}^{-1}\right.$ [98]); therefore, it cannot effectively compete for ${ }^{\bullet} \mathrm{OH}$ with the sulfonamides. $\mathrm{HCO}_{3}{ }^{-}$also reported as an efficient scavenger of $\mathrm{h}_{\mathrm{VB}}{ }^{+}$, resulting in the formation of carbonate radicals $\left(\mathrm{CO}_{3}{ }^{-}-\right)[61,105]$ on the surface of $\mathrm{TiO}_{2}$. The formed $\mathrm{CO}_{3}{ }^{\bullet-}$ is a more selective oxidant than ${ }^{\bullet} \mathrm{OH}$, but sulfonamides, especially SMP, are re-

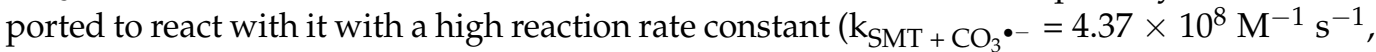
$\mathrm{k}_{\mathrm{SMP}+\mathrm{CO}_{3}{ }^{--}}=8.71 \times 10^{8} \mathrm{M}^{-1} \mathrm{~s}^{-1}$ [106]). The negligible effect of $\mathrm{HCO}_{3}{ }^{-}$during most of the measurements, and the relatively low effect of the matrices on the transformation rates might be due to the reaction of sulfonamides with formed $\mathrm{CO}_{3}{ }^{\bullet-}$.

The $\mathrm{Cl}^{-}$does not react with $\mathrm{h}_{\mathrm{VB}}{ }^{+}$, and generally has a negligible effect on photocatalytic activity using $\mathrm{TiO}_{2}$ [61]. It may react with $\bullet{ }^{\bullet} \mathrm{OH}$ with a high reaction rate $\left(\mathrm{k}=4.3 \times 10^{9} \mathrm{M}^{-1} \mathrm{~s}^{-1}\right.$ [107]) to form chlorine radicals, but at neutral and alkaline $\mathrm{pH}$ the backward reaction leading to the reformation of ${ }^{\bullet} \mathrm{OH}$ is favored [62]. In the case of $\mathrm{ZnO}$, adsorption of $\mathrm{Cl}^{-}$on the surface can promote the separation of photogenerated charges, leading to higher photocatalytic efficiency [108]. Its significantly negative effect can be observed only for SMP, using $\mathrm{TiO}_{2} / \mathrm{LED}_{398 \mathrm{~nm}}$ process. The transformation of SMP using $\mathrm{TiO}_{2}$ and $\mathrm{LED}_{398 \mathrm{~nm}}$ is most likely caused by the energy transfer-with some contribution of the charge transition-which is especially sensitive to the surface conditions. 

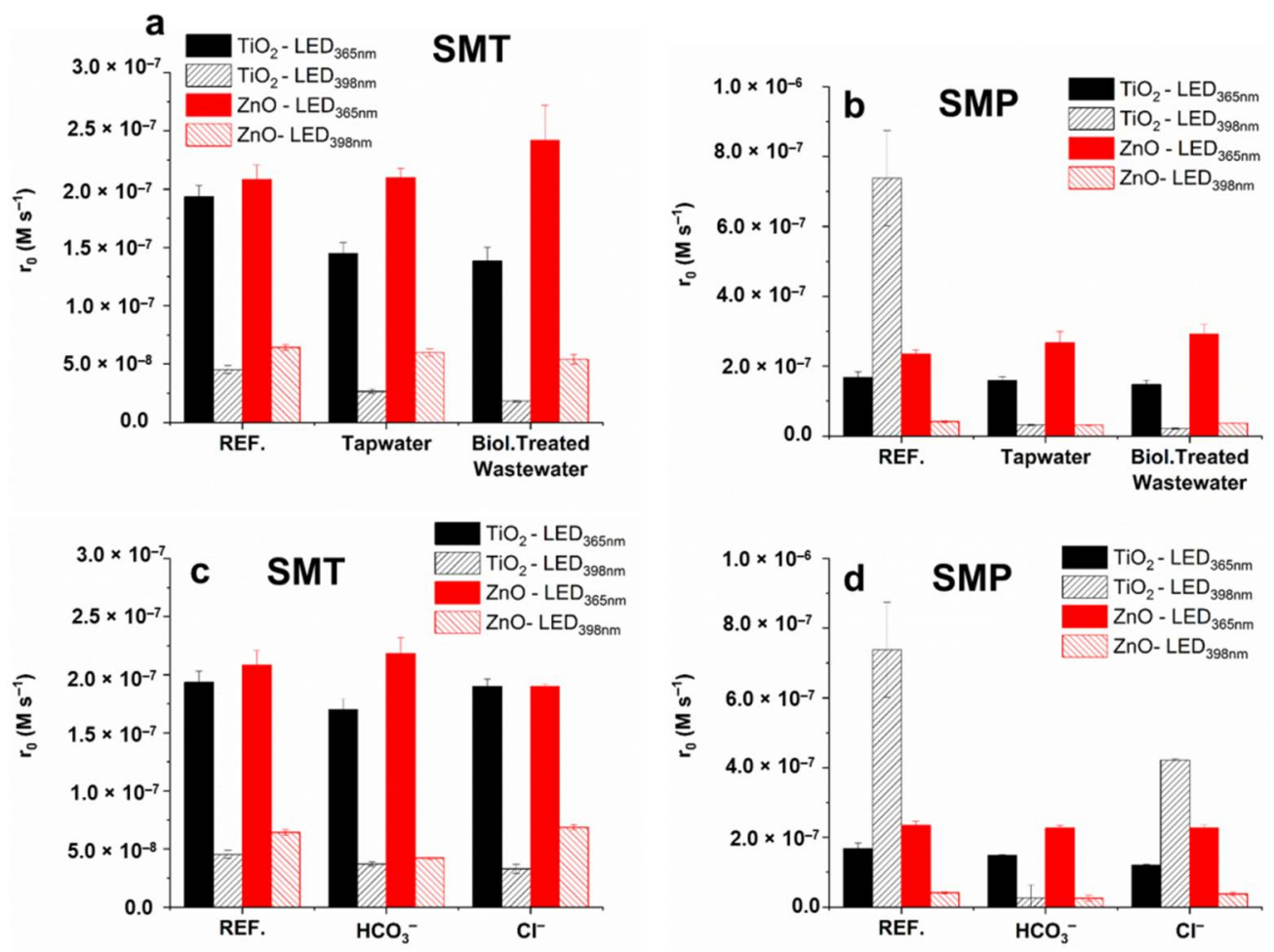

Figure 10. The initial reaction rates of SMT $(\mathbf{a}, \mathbf{c})$ and SMP $(\mathbf{b}, \mathbf{d})$ determined in purified water $(\mathrm{REF})$, real water matrices (tapwater and biologically treated domestic wastewater), and in the presence of $\mathrm{Cl}^{-}\left(120 \mathrm{mg} \mathrm{dm}^{-3}\right)$ and $\mathrm{HCO}_{3}^{-}\left(525 \mathrm{mg} \mathrm{dm}^{-3}\right)$.

\section{Conclusions}

Heterogeneous photocatalysis is generally considered to be based primarily on electron transfer reactions at the surface of the irradiated semiconductor. Besides radical-based reactions and direct charge transfer, attention recently moved towards photocatalytic syntheses, requiring selective transformation. Some examples have been reported in the literature when the transformation is due to the energy transfer between excited semiconductor as energy donor, and results in selective transformation of organic substances.

The present work compares the efficiency of the commercially available photocatalysts, $\mathrm{TiO}_{2}$ and $\mathrm{ZnO}$ irradiated with $365 \mathrm{~nm}$ or $398 \mathrm{~nm}$. Two sulfonamide antibiotics, SMT and SMP, were used to compare the efficiency of the photocatalysts under 398 and $365 \mathrm{~nm}$ radiation. The results showed that, besides ${ }^{\bullet} \mathrm{OH}$-based reaction, the direct charge transfer contributes to the transformation even in the case of $\mathrm{ZnO}$. Consequently, the transformation was faster when $\mathrm{ZnO}$ was applied; however, $\mathrm{TiO}_{2}$ was more efficient in mineralization. The unique behavior, an exceptionally fast transformation of SMP was observed, in the case of $\mathrm{TiO}_{2} / \mathrm{LED}_{398 \mathrm{~nm}}$ process, in contrast to the other cases when $365 \mathrm{~nm}$ light was more efficient than $398 \mathrm{~nm}$ light. The transformation of SMP was fast in both $\mathrm{O}_{2}$ containing and $\mathrm{O}_{2}$-free $\mathrm{TiO}_{2}$ suspensions and takes place via desulfonation, while in other cases, mainly hydroxylated products form. The effect of reaction parameters confirmed that a quite rarely observed direct energy transfer between the excited state P25 and SMP is likely responsible for this unique behavior; however, the role of direct charge transfer cannot be excluded completely.

Our results have highlighted that "non-conventional" mechanisms can occur in exceptional cases during heterogeneous photocatalysis (even in the case of the well-known photocatalyst, such as $\mathrm{TiO}_{2}$ ), and the effect of wavelength is also worth investigating. The presented results may contribute to further studies on the application of photocatalysts, either in the selective removal of organic pollutants or in the field of organic chemical synthesis. 
Supplementary Materials: The following supporting information can be downloaded at: https: / /www.mdpi.com/article/10.3390/ma15010049/s1, Figure S1: The schematic figure of the photoreactors (a: $\mathrm{LED}_{365 \mathrm{~nm}}$, b: $\mathrm{LED}_{398 \mathrm{~nm}}$ ); Figure S2: The peak area (HPLC-DAD) of the products of SMT transformation as a function of irradiation time; Figure S3: The peak area (HPLC-DAD) of the products of SMP transformation as a function of irradiation time; Figure S4: The transformation of organic nitrogen and sulfur to inorganic ions during the photocatalytic removal of SMT (Mineralization(\%) = concentration of given ion divided by the organic N-content or S-content of the starting solution); Figure S5: The transformation of organic nitrogen and sulfur to inorganic ions during the photocatalytic removal of SMP (Mineralization( $\%)=$ concentration of given ion divided by the organic N-content or S-content of the starting solution); Table S1: The list of used chemicals, their distributors and purity; Table S2: The measured, relevant parameters of the real water matrices.

Author Contributions: M.N.: experimental work, visualization, writing and editing the initial draft; L.F.: experimental work and editing; G.B.: ionchromatography measurement; G.K.: XRD and DRS measurement; K.H.: review and evaluation; T.A.: conceptualization; formulating and managing research goals and work, evaluating results, writing-review \& editing. All authors have read and agreed to the published version of the manuscript.

Funding: Tünde Alapi acknowledges the support of the János Bolyai Research Scholarship of the Hungarian Academy of Sciences. The work was financed by the New National Excellence Program of the Ministry for Innovation and Technology (ÚNKP-21-4-SZTE-494, and ÚNKP-21-5-SZTE-594) and the National Research, Development and Innovation Office-NKFI Fund OTKA, project number FK132742.

Data Availability Statement: The data is included in the article or Supplementary Material.

Conflicts of Interest: The authors declare no conflict of interest.

\section{References}

1. Tacconelli, E.; Carrara, E.; Savoldi, A.; Harbarth, S.; Mendelson, M.; Monnet, D.L.; Pulcini, C.; Kahlmeter, G.; Kluytmans, J.; Carmeli, Y.; et al. Discovery, Research, and Development of New Antibiotics: The WHO Priority List of Antibiotic-Resistant Bacteria and Tuberculosis. Lancet Infect. Dis. 2018, 18, 318-327. [CrossRef]

2. Falowo, A.B.; Akimoladun, O.F. Veterinary drug residues in meat and meat products: Occurrence, detection and implications. In Veterinary Medicine and Pharmaceuticals; Bekoe, S.O., Saravanan, M., Eds.; IntechOpen: London, UK, 2020. [CrossRef]

3. Tacic, A.; Nikolic, V.; Nikolic, L.; Savic, I. Antimicrobial Sulfonamide Drugs. Adv. Technol. 2017, 6, 58-71. [CrossRef]

4. Klauson, D.; Romero Sarcos, N.; Krichevskaya, M.; Kattel, E.; Dulova, N.; Dedova, T.; Trapido, M. Advanced Oxidation Processes for Sulfonamide Antibiotic Sulfamethizole Degradation: Process Applicability Study at ppm Level and Scale-down to ppb Level. J. Environ. Chem. Eng. 2019, 7, 103287. [CrossRef]

5. Wang, J.; Chu, L.; Wojnárovits, L.; Takács, E. Occurrence and Fate of Antibiotics, Antibiotic Resistant Genes (ARGs) and Antibiotic Resistant Bacteria (ARB) in Municipal Wastewater Treatment Plant: An Overview. Sci. Total Environ. 2020, 744, 140997. [CrossRef]

6. Mendiola-Alvarez, S.Y.; Palomino-Cabello, C.; Hernández-Ramírez, A.; Turnes-Palomino, G.; Guzmán-Mar, J.L.; Hinojosa-Reyes, L. Coupled Heterogeneous Photocatalysis Using a $\mathrm{P}-\mathrm{TiO}_{2}-\mathrm{AFe}_{2} \mathrm{O}_{3}$ Catalyst and $\mathrm{K}_{2} \mathrm{~S}_{2} \mathrm{O}_{8}$ for the Efficient Degradation of a Sulfonamide Mixture. J. Photochem. Photobiol. A Chem. 2020, 394, 112485. [CrossRef]

7. Li, P.; Guo, M.; Wang, Q.; Li, Z.; Wang, C.C.C.; Chen, N.; Wang, C.C.C.; Wan, C.; Chen, S. Controllable Synthesis of Cerium Zirconium Oxide Nanocomposites and Their Application for Photocatalytic Degradation of Sulfonamides. Appl. Catal. B Environ. 2019, 259, 118107. [CrossRef]

8. Estrada-Flórez, S.E.; Serna-Galvis, E.A.; Torres-Palma, R.A. Photocatalytic vs. Sonochemical Removal of Antibiotics in Water: Structure-Degradability Relationship, Mineralization, Antimicrobial Activity, and Matrix Effects. J. Environ. Chem. Eng. 2020, 8, 104359. [CrossRef]

9. Wu, C.H.; Kuo, C.Y.; Dong, C.D.; Chen, C.W.; Lin, Y.L. Removal of Sulfonamides from Wastewater in the UV/TiO 2 System: Effects of PH and Salinity on Photodegradation and Mineralization. Water Sci. Technol. 2019, 79, 349-355. [CrossRef] [PubMed]

10. Zhang, J.; Li, J.; Su, H.; Zhao, Y.; Zeng, X.; Hu, M.; Xiao, W.; Mao, X. H-Bonding Effect of Oxyanions Enhanced Photocatalytic Degradation of Sulfonamides by g-C3N4 in Aqueous Solution. J. Hazard. Mater. 2019, 366, 259-267. [CrossRef]

11. Song, Y.; Tian, J.; Gao, S.; Shao, P.; Qi, J.; Cui, F. Photodegradation of Sulfonamides by G-C ${ }_{3} \mathrm{~N}_{4}$ under Visible Light Irradiation: Effectiveness, Mechanism and Pathways. Appl. Catal. B Environ. 2017, 210, 88-96. [CrossRef]

12. Chen, P.; Zhang, Q.; Zheng, X.; Tan, C.; Zhuo, M.; Chen, T.; Wang, F.; Liu, H.; Liu, Y.; Feng, Y.; et al. Phosphate-Modified $\mathrm{m}-\mathrm{Bi}_{2} \mathrm{O}_{4}$ Enhances the Absorption and Photocatalytic Activities of Sulfonamide: Mechanism, Reactive Species, and Reactive Sites. J. Hazard. Mater. 2020, 384, 121443. [CrossRef]

13. Wang, W.; Tian, J.; Zhu, Z.; Zhu, C.; Liu, B.; Hu, C. Insight into Quinolones and Sulfonamides Degradation, Intermediate Product Identification and Decomposition Pathways with the Assistance of $\mathrm{Bi}_{2} \mathrm{MoO}_{6} / \mathrm{Bi}_{2} \mathrm{WO}_{6} / \mathrm{MWCNTs}$ Photocatalyst. Process Saf. Environ. Prot. 2021, 147, 527-546. [CrossRef] 
14. Zhu, W.; Sun, F.; Goei, R.; Zhou, Y. Facile Fabrication of RGO-WO $\mathrm{WO}_{3}$ Composites for Effective Visible Light Photocatalytic Degradation of Sulfamethoxazole. Appl. Catal. B Environ. 2017, 207, 93-102. [CrossRef]

15. Yang, C.C.; Huang, C.L.; Cheng, T.C.; Lai, H.T. Inhibitory Effect of Salinity on the Photocatalytic Degradation of Three Sulfonamide Antibiotics. Int. Biodeterior. Biodegrad. 2015, 102, 116-125. [CrossRef]

16. Kaniou, S.; Pitarakis, K.; Barlagianni, I.; Poulios, I. Photocatalytic Oxidation of Sulfamethazine. Chemosphere 2005, 60, 372-380. [CrossRef] [PubMed]

17. Baran, W.; Sochacka, J.; Wardas, W. Toxicity and Biodegradability of Sulfonamides and Products of Their Photocatalytic Degradation in Aqueous Solutions. Chemosphere 2006, 65, 1295-1299. [CrossRef]

18. Ahmed, S.; Rasul, M.G.; Brown, R.; Hashib, M.A. Influence of Parameters on the Heterogeneous Photocatalytic Degradation of Pesticides and Phenolic Contaminants in Wastewater: A Short Review. J. Environ. Manag. 2011, 92, 311-330. [CrossRef] [PubMed]

19. Younis, S.A.; Kim, K.H. Heterogeneous Photocatalysis Scalability for Environmental Remediation: Opportunities and Challenges. Catalysts 2020, 11, 1109. [CrossRef]

20. Bellardita, M.; Ceccato, R.; Dirè, S.; Loddo, V.; Palmisano, L.; Parrino, F. Energy Transfer in Heterogeneous Photocatalysis. Subst. Int. J. Hist. Chem. 2019, 3, 49-57. [CrossRef]

21. Nosaka, Y.; Daimon, T.; Nosaka, A.Y.; Murakami, Y. Singlet Oxygen Formation in Photocatalytic TiO 2 Aqueous Suspension. Phys. Chem. Chem. Phys. 2004, 6, 2917-2918. [CrossRef]

22. Jańczyk, A.; Krakowska, E.; Stochel, G.; Macyk, W. Singlet Oxygen Photogeneration at Surface Modified Titanium Dioxide. J. Am. Chem. Soc. 2006, 128, 15574-15575. [CrossRef] [PubMed]

23. Buchalska, M.; Łabuz, P.; Bujak, Ł.; Szewczyk, G.; Sarna, T.; Maćkowski, S.; Macyk, W. New Insight into Singlet Oxygen Generation at Surface Modified Nanocrystalline $\mathrm{TiO}_{2}$ - the Effect of near-Infrared Irradiation. J. Chem. Soc. Dalt. Trans. 2013, 42, $9468-9475$. [CrossRef]

24. Ciriminna, R.; Parrino, F.; De Pasquale, C.; Palmisano, L.; Pagliaro, M. Photocatalytic Partial Oxidation of Limonene to 1,2 Limonene Oxide. Chem. Commun. 2018, 54, 1008-1011. [CrossRef]

25. Parrino, F.; Fidalgo, A.; Palmisano, L.; Ilharco, L.M.; Pagliaro, M.; Ciriminna, R. Polymers of Limonene Oxide and Carbon Dioxide: Polycarbonates of the Solar Economy. ACS Omega 2018, 3, 4884-4890. [CrossRef] [PubMed]

26. Parrino, F.; Di Paola, A.; Loddo, V.; Pibiri, I.; Bellardita, M.; Palmisano, L. Photochemical and Photocatalytic Isomerization of Trans-Caffeic Acid and Cyclization of Cis-Caffeic Acid to Esculetin. Appl. Catal. B Environ. 2016, 182, 347-355. [CrossRef]

27. Srikant, V.; Clarke, D.R. On the Optical Band Gap of Zinc Oxide. J. Appl. Phys. 1998, 83, 5447-5451. [CrossRef]

28. Kafizas, A.; Wang, X.; Pendlebury, S.R.; Barnes, P.; Ling, M.; Sotelo-Vazquez, C.; Quesada-Cabrera, R.; Li, C.; Parkin, I.P.; Durrant, J.R. Where Do Photogenerated Holes Go in Anatase:Rutile $\mathrm{TiO}_{2}$ ? A Transient Absorption Spectroscopy Study of Charge Transfer and Lifetime. J. Phys. Chem. A 2016, 120, 715-723. [CrossRef]

29. Rohilla, S.; Gupta, A.; Kumar, V.; Kumari, S.; Petru, M.; Amor, N.; Noman, M.T.; Dalal, J. Excellent Uv-light Triggered Photocatalytic Performance of $\mathrm{Zno}_{\mathrm{SiO}} \mathrm{S}_{2}$ Nanocomposite for Water Pollutant Compound Methyl Orange Dye. Nanomaterials 2021, 11, 2548. [CrossRef] [PubMed]

30. Ohno, T.; Sarukawa, K.; Tokieda, K.; Matsumura, M. Morphology of a $\mathrm{TiO}_{2}$ Photocatalyst (Degussa, P-25) Consisting of Anatase and Rutile Crystalline Phases. J. Catal. 2001, 203, 82-86. [CrossRef]

31. Datye, A.K.; Riegel, G.; Bolton, J.R.; Huang, M.; Prairie, M.R. Microstructural Characterization of a Fumed Titanium Dioxide Photocatalyst. J. Solid State Chem. 1995, 115, 236-239. [CrossRef]

32. Bickley, R.I.; Gonzalez-Carreno, T.; Lees, J.S.; Palmisano, L.; Tilley, R.J.D. A Structural Investigation of Titanium Dioxide Photocatalysts. J. Solid State Chem. 1991, 92, 178-190. [CrossRef]

33. Hurum, D.C.; Agrios, A.G.; Gray, K.A.; Rajh, T.; Thurnauer, M.C. Explaining the Enhanced Photocatalytic Activity of Degussa P25 Mixed-Phase $\mathrm{TiO}_{2}$ Using EPR. J. Phys. Chem. B 2003, 107, 4545-4549. [CrossRef]

34. MacDonald, I.R.; Howe, R.F.; Zhang, X.; Zhou, W. In Situ EPR Studies of Electron Trapping in a Nanocrystalline Rutile J. Photochem. Photobiol. A Chem. 2010, 216, 238-243. [CrossRef]

35. MacDonald, I.R.; Rhydderch, S.; Holt, E.; Grant, N.; Storey, J.M.D.; Howe, R.F. EPR Studies of Electron and Hole Trapping in Titania Photocatalysts. Catal. Today 2012, 182, 39-45. [CrossRef]

36. Jiang, X.; Manawan, M.; Feng, T.; Qian, R.; Zhao, T.; Zhou, G.; Kong, F.; Wang, Q.; Dai, S.; Pan, J.H. Anatase and Rutile in Evonik Aeroxide P25: Heterojunctioned or Individual Nanoparticles? Catal. Today 2018, 300, 12-17. [CrossRef]

37. Ohtani, B.; Prieto-Mahaney, O.O.; Li, D.; Abe, R. What Is Degussa (Evonic) P25? Crystalline Composition Analysis, Reconstruction from Isolated Pure Particles and Photocatalytic Activity Test. J. Photochem. Photobiol. A Chem. 2010, 216, 179-182. [CrossRef]

38. Prieto-Mahaney, O.O.; Murakami, N.; Abe, R.; Ohtani, B. Correlation between Photoeatalytic Activities and Structural and Physical Properties of Titanium(IV) Oxide Powders. Chem. Lett. 2009, 38, 238-239. [CrossRef]

39. Ide, Y.; Inami, N.; Hattori, H.; Saito, K.; Sohmiya, M.; Tsunoji, N.; Komaguchi, K.; Sano, T.; Bando, Y.; Golberg, D.; et al. Remarkable

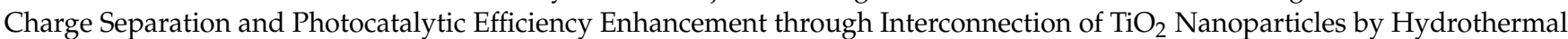
Treatment. Angew. Chem. Int. Ed. 2016, 55, 3600-3605. [CrossRef]

40. Zhang, H.; Chen, G.; Bahnemann, D.W. Photoelectrocatalytic Materials for Environmental Applications. J. Mater. Chem. 2009, $19,5089-5121$. [CrossRef]

41. Deng, X.; Chen, Y.; Wen, J.; Xu, Y.; Zhu, J.; Bian, Z. Polyaniline-TiO ${ }_{2}$ Composite Photocatalysts for Light-Driven Hexavalent Chromium Ions Reduction. Sci. Bull. 2020, 65, 105-112. [CrossRef] 


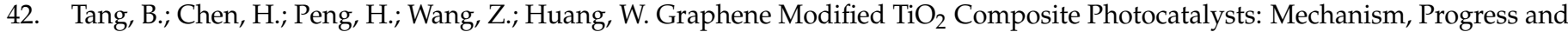
Perspective. Nanomaterials 2018, 8, 105. [CrossRef]

43. Qin, R.; Meng, F.; Khan, M.W.; Yu, B.; Li, H.; Fan, Z.; Gong, J. Fabrication and Enhanced Photocatalytic Property of TiO 2 -ZnO Composite Photocatalysts. Mater. Lett. 2019, 240, 84-87. [CrossRef]

44. Kumari, S.; Malik, S.; Kumar, S.; Dalal, J.; Dahiya, S.; Ohlan, A.; Punia, R.; Maan, A.S. Excellent Photoelectrical Properties of ZnO Thin Film Based on ZnO /Epoxy-Resin Ink for UV-Light Detectors. AIP Conf. Proc. 2019, 2142, 120004. [CrossRef]

45. Dossin Zanrosso, C.; Piazza, D.; Lansarin, M.A. PVDF/ZnO Composite Films for Photocatalysis: A Comparative Study of Solution Mixing and Melt Blending Methods. Polym. Eng. Sci. 2020, 60, 1146-1157. [CrossRef]

46. Mirikaram, N.; Pérez-molina, Á.; Morales-torres, S.; Salemi, A.; Maldonado-hódar, F.J.; Pastrana-martínez, L.M. Photocatalytic Perfomance of Zno-graphene Oxide Composites towards the Degradation of Vanillic Acid under Solar Radiation and Visibleled. Nanomaterials 2021, 11, 1576. [CrossRef]

47. Raha, S.; Mohanta, D.; Ahmaruzzaman, M. Novel CuO/ $\mathrm{Mn}_{3} \mathrm{O}_{4} / \mathrm{ZnO}$ Nanocomposite with Superior Photocatalytic Activity for Removal of Rabeprazole from Water. Sci. Rep. 2021, 11, 15187. [CrossRef] [PubMed]

48. Thangadurai, P.; Beura, R.; Kumar, J.S. Nanomaterials with different morphologies for photocatalysis. In Green Photocatalysts; Naushad, M., Rajendran, S., Lichfouse, E., Eds.; Springer: Berlin/Heidelberg, Germany, 2020; ISBN 9783540228608.

49. Yang, H.; Li, G.; An, T.; Gao, Y.; Fu, J. Photocatalytic Degradation Kinetics and Mechanism of Environmental Pharmaceuticals in Aqueous Suspension of $\mathrm{TiO}_{2}$ : A Case of Sulfa Drugs. Catal. Today 2010, 153, 200-207. [CrossRef]

50. Mirzaei, A.; Yerushalmi, L.; Chen, Z.; Haghighat, F.; Guo, J. Enhanced Photocatalytic Degradation of Sulfamethoxazole by Zinc Oxide Photocatalyst in the Presence of Fluoride Ions: Optimization of Parameters and Toxicological Evaluation. Water Res. 2018, 132, 241-251. [CrossRef] [PubMed]

51. Náfrádi, M.; Hernadi, K.; Kónya, Z.; Alapi, T. Investigation of the Efficiency of BiOI/BiOCl Composite Photocatalysts Using UV, Cool and Warm White LED Light Sources-Photon Efficiency, Toxicity, Reusability, Matrix Effect, and Energy Consumption. Chemosphere 2021, 280, 130636. [CrossRef] [PubMed]

52. Khan, J.A.; Sayed, M.; Khan, S.; Shah, N.S.; Dionysiou, D.D.; Boczkaj, G. Advanced oxidation processes for the treatment of contaminants of emerging concern. In Contaminants of Emerging Concern in Water and Wastewater; Hernandez-Maldonado, A., Blaney, L., Eds.; Elsevier Inc.: Amsterdam, The Netherlands, 2019; ISBN 9780128135617.

53. Bertagna Silva, D.; Buttiglieri, G.; Babić, S. State-of-the-Art and Current Challenges for TiO2/UV-LED Photocatalytic Degradation of Emerging Organic Micropollutants. Environ. Sci. Pollut. Res. 2021, 28, 103-120. [CrossRef] [PubMed]

54. Jo, W.K.; Tayade, R.J. New Generation Energy-Efficient Light Source for Photocatalysis: LEDs for Environmental Applications. Ind. Eng. Chem. Res. 2014, 53, 2073-2084. [CrossRef]

55. Tokode, O.; Prabhu, R.; Lawton, L.A.; Robertson, P.K.J. UV LED Sources for Heterogeneous Photocatalysis. Handb. Environ. Chem. 2015, 35, 159-179. [CrossRef]

56. Eskandarian, M.R.; Choi, H.; Fazli, M.; Rasoulifard, M.H. Effect of UV-LED Wavelengths on Direct Photolytic and TiO 2 Photocatalytic Degradation of Emerging Contaminants in Water. Chem. Eng. J. 2016, 300, 414-422. [CrossRef]

57. Biancullo, F.; Moreira, N.F.F.; Ribeiro, A.R.; Manaia, C.M.; Faria, J.L.; Nunes, O.C.; Castro-Silva, S.M.; Silva, A.M.T. Heterogeneous Photocatalysis Using UVA-LEDs for the Removal of Antibiotics and Antibiotic Resistant Bacteria from Urban Wastewater Treatment Plant Effluents. Chem. Eng. J. 2019, 367, 304-313. [CrossRef]

58. Takeda, K.; Fujisawa, K.; Nojima, H.; Kato, R.; Ueki, R.; Sakugawa, H. Hydroxyl Radical Generation with a High Power Ultraviolet Light Emitting Diode (UV-LED) and Application for Determination of Hydroxyl Radical Reaction Rate Constants. J. Photochem. Photobiol. A Chem. 2017, 340, 8-14. [CrossRef]

59. Taghavi, M.; Ghaneian, M.T.; Ehrampoush, M.H.; Tabatabaee, M.; Afsharnia, M.; Alami, A.; Mardaneh, J. Feasibility of Applying the LED-UV-Induced $\mathrm{TiO}_{2} / \mathrm{ZnO}$-Supported $\mathrm{H}_{3} \mathrm{PMo}_{12} \mathrm{O}_{40}$ Nanoparticles in Photocatalytic Degradation of Aniline. Environ. Monit. Assess. 2018, 190, 188. [CrossRef] [PubMed]

60. Khademalrasool, M.; Farbod, M.; Talebzadeh, M.D. The Improvement of Photocatalytic Processes: Design of a Photoreactor Using High-Power LEDs. J. Sci. Adv. Mater. Devices 2016, 1, 382-387. [CrossRef]

61. Farner Budarz, J.; Turolla, A.; Piasecki, A.F.; Bottero, J.Y.; Antonelli, M.; Wiesner, M.R. Influence of Aqueous Inorganic Anions on the Reactivity of Nanoparticles in $\mathrm{TiO}_{2}$ Photocatalysis. Langmuir 2017, 33, 2770-2779. [CrossRef] [PubMed]

62. Bouanimba, N.; Laid, N.; Zouaghi, R.; Sehili, T. A Comparative Study of the Activity of $\mathrm{TiO}_{2}$ Degussa P25 and Millennium PCs in the Photocatalytic Degradation of Bromothymol Blue. Int. J. Chem. React. Eng. 2018, 16, 1-19. [CrossRef]

63. Serrà, A.; Philippe, L.; Perreault, F.; Garcia-Segura, S. Photocatalytic Treatment of Natural Waters. Reality or Hype? The Case of Cyanotoxins Remediation. Water Res. 2021, 188, 116543. [CrossRef]

64. Tufail, A.; Price, W.E.; Mohseni, M.; Pramanik, B.K.; Hai, F.I. A Critical Review of Advanced Oxidation Processes for Emerging Trace Organic Contaminant Degradation: Mechanisms, Factors, Degradation Products, and Effluent Toxicity. J. Water Process Eng. 2021, 40, 101778. [CrossRef]

65. Kudlek, E.; Dudziak, M.; Bohdziewicz, J. Influence of Inorganic Ions and Organic Substances on the Degradation of Pharmaceutical Compound in Water Matrix. Water 2016, 8, 532. [CrossRef]

66. Guillard, C.; Puzenat, E.; Lachheb, H.; Houas, A.; Herrmann, J.M. Why Inorganic Salts Decrease the TiO 2 Photocatalytic Efficiency. Int. J. Photoenergy 2005, 7, 641208. [CrossRef] 
67. Šojić Merkulov, D.V.; Lazarević, M.J.; Despotović, V.N.; Banić, N.D.; Finčur, N.L.; Maletić, S.P.; Abramović, B.F. The Effects of Inorganic Anions and Organic Matter on Mesotrione (Callisto $\left.{ }^{\circledR}\right)$ Removal from Environmental Waters. J. Serbian Chem. Soc. 2017, 82, 343-355. [CrossRef]

68. Lado Ribeiro, A.R.; Moreira, N.F.F.; Li Puma, G.; Silva, A.M.T. Impact of Water Matrix on the Removal of Micropollutants by Advanced Oxidation Technologies. Chem. Eng. J. 2019, 363, 155-173. [CrossRef]

69. Hatchard, C.G.; Parker, C.A. A New Sensitive Chemical Actinometer-II. Potassium Ferrioxalate as a Standard Chemical Actinometer. Proc. R. Soc. London Ser. A Math. Phys. Sci. 1956, 235, 518-536. [CrossRef]

70. Zuccheri, T.; Colonna, M.; Stefanini, I.; Santini, C.; Di Gioia, D. Bactericidal Activity of Aqueous Acrylic Paint Dispersion for Wooden Substrates Based on $\mathrm{TiO}_{2}$ Nanoparticles Activated by Fluorescent Light. Materials 2013, 6, 3270-3283. [CrossRef]

71. Hassellöv, M.; Readman, J.W.; Ranville, J.F.; Tiede, K. Nanoparticle Analysis and Characterization Methodologies in Environmental Risk Assessment of Engineered Nanoparticles. Ecotoxicology 2008, 17, 344-361. [CrossRef]

72. White, L.; Koo, Y.; Yun, Y.; Sankar, J. TiO 2 Deposition on AZ31 Magnesium Alloy Using Plasma Electrolytic Oxidation. J. Nanomater. 2013, 2013, 11. [CrossRef]

73. Thamaphat, K.; Limsuwan, P.; Ngotawornchai, B. Phase Characterization of $\mathrm{TiO}_{2}$ Powder by XRD and TEM. Agric. Nat. Resour. 2008, 42, 357-361.

74. Arefi, M.R.; Rezaei-Zarchi, S. Synthesis of Zinc Oxide Nanoparticles and Their Effect on the Compressive Strength and Setting Time of Self-Compacted Concrete Paste as Cementitious Composites. Int. J. Mol. Sci. 2012, 13, 4340-4350. [CrossRef]

75. Yi, Z.; Wang, J.; Jiang, T.; Tang, Q.; Cheng, Y. Photocatalytic Degradation of Sulfamethazine in Aqueous Solution Using Zno with Different Morphologies. R. Soc. Open Sci. 2018, 5, 171457. [CrossRef]

76. Zhu, G.; Sun, Q.; Wang, C.; Yang, Z.; Xue, Q. Removal of Sulfamethoxazole, Sulfathiazole and Sulfamethazine in Their Mixed Solution by UV $/ \mathrm{H}_{2} \mathrm{O}_{2}$ Process. Int. J. Environ. Res. Public Health 2019, 16, 1797. [CrossRef] [PubMed]

77. Shah, S.; Hao, C. Quantum Chemical Investigation on Photodegradation Mechanisms of Sulfamethoxypyridazine with Dissolved Inorganic Matter and Hydroxyl Radical. J. Environ. Sci. 2017, 57, 85-92. [CrossRef]

78. Guo, C.; Xu, J.; Wang, S.; Zhang, Y.; He, Y.; Li, X. Photodegradation of Sulfamethazine in an Aqueous Solution by a Bismuth Molybdate Photocatalyst. Catal. Sci. Technol. 2013, 3, 1603-1611. [CrossRef]

79. Yang, L.; Shi, Y.; Li, J.; Fang, L.; Luan, T. Transformation of Aqueous Sulfonamides under Horseradish Peroxidase and Characterization of Sulfur Dioxide Extrusion Products from Sulfadiazine. Chemosphere 2018, 200, 164-172. [CrossRef]

80. Boreen, A.L.; Arnold, W.A.; McNeill, K. Triplet-Sensitized Photodegradation of Sulfa Drugs Containing Six-Membered Heterocyclic Groups: Identification of an $\mathrm{SO}_{2}$ Extrusion Photoproduct. Environ. Sci. Technol. 2005, 39, 3630-3638. [CrossRef]

81. Ge, L.; Zhang, P.; Halsall, C.; Li, Y.; Chen, C.E.; Li, J.; Sun, H.; Yao, Z. The Importance of Reactive Oxygen Species on the Aqueous Phototransformation of Sulfonamide Antibiotics: Kinetics, Pathways, and Comparisons with Direct Photolysis. Water Res. 2019, 149, 243-250. [CrossRef]

82. Park, S.; Kim, H.J.; Kim, J.S.; Yoo, K.; Lee, J.C.; Anderson, W.A.; Lee, J.H. Photocatalytic Reduction of Nitrate in Wastewater Using ZnO Nanopowder Synthesized by Solution Combustion Method. J. Nanosci. Nanotechnol. 2007, 7, 4069-4072. [CrossRef] [PubMed]

83. Løgager, T.; Sehested, K. Formation and Decay of Peroxynitric Acid: A Pulse Radiolysis Study. J. Phys. Chem. 1993, 97, 10047-10052. [CrossRef]

84. Náfrádi, M.; Farkas, L.; Alapi, T.; Hernádi, K.; Kovács, K.; Wojnárovits, L.; Takács, E. Application of Coumarin and Coumarin-3Carboxylic Acid for the Determination of Hydroxyl Radicals during Different Advanced Oxidation Processes. Radiat. Phys. Chem. 2020, 170, 108610. [CrossRef]

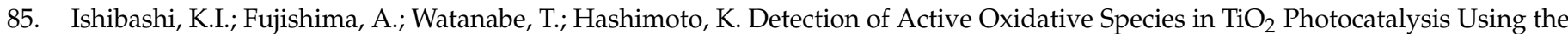
Fluorescence Technique. Electrochem. Commun. 2000, 2, 207-210. [CrossRef]

86. Zhang, J.; Nosaka, Y. Quantitative Detection of OH Radicals for Investigating the Reaction Mechanism of Various Visible-Light $\mathrm{TiO}_{2}$ Photocatalysts in Aqueous Suspension. J. Phys. Chem. C 2013, 117, 1383-1391. [CrossRef]

87. Zhang, J.; Nosaka, Y. Generation of $\mathrm{OH}$ Radicals and Oxidation Mechanism in Photocatalysis of $\mathrm{WO}_{3}$ and $\mathrm{BiVO}_{4} \mathrm{Powders}$ J. Photochem. Photobiol. A Chem. 2015, 303-304, 53-58. [CrossRef]

88. Černigoj, U.; Štangar, U.L.; Trebše, P.; Sarakha, M. Determination of Catalytic Properties of $\mathrm{TiO}_{2}$ Coatings Using Aqueous Solution of Coumarin: Standardization Efforts. J. Photochem. Photobiol. A Chem. 2009, 201, 142-150. [CrossRef]

89. Baxter, J.B.; Schmuttenmaer, C.A. Conductivity of ZnO Nanowires, Nanoparticles, and Thin Films Using Time-Resolved Terahertz Spectroscopy. J. Phys. Chem. B 2006, 110, 25229-25239. [CrossRef] [PubMed]

90. Meulenkamp, E.A. Electron Transport in Nanoparticulate ZnO Films. J. Phys. Chem. B 1999, 103, 7831-7838. [CrossRef]

91. Sachs, M.; Pastor, E.; Kafizas, A.; Durrant, J.R. Evaluation of Surface State Mediated Charge Recombination in Anatase and Rutile $\mathrm{TiO}_{2}$. J. Phys. Chem. Lett. 2016, 7, 3742-3746. [CrossRef]

92. Tang, J.; Durrant, J.R.; Klug, D.R. Mechanism of Photocatalytic Water Splitting in $\mathrm{TiO}_{2}$. Reaction of Water with Photoholes, Importance of Charge Carrier Dynamics, and Evidence for Four-Hole Chemistry. J. Am. Chem. Soc. 2008, 130, 13885-13891. [CrossRef] [PubMed]

93. Fónagy, O.; Szabó-Bárdos, E.; Horváth, O. 1,4-Benzoquinone and 1,4-Hydroquinone Based Determination of Electron and Superoxide Radical Formed in Heterogeneous Photocatalytic Systems. J. Photochem. Photobiol. A Chem. 2021, 407, 113057. [CrossRef] 
94. Henderson, M.A.; Shen, M. Electron-Scavenging Chemistry of Benzoquinone on $\mathrm{TiO}_{2}(110)$. Top. Catal. 2017, 60, 440-445. [CrossRef]

95. Adams, G.E.; Michael, B.D. Pulse Radiolysis of Benzoquinone and Hydroquinone. Semiquinone Formation by Water Elimination from Trihydroxycyclohexadienyl Radicals. Trans. Faraday Soc. 1967, 63, 1171-1180. [CrossRef]

96. Al-Suhybani, A.A.; Hughes, G. Pulse Radiolysis of Hydroquinone Solutions in the Presence of $\mathrm{N}_{2} \mathrm{O}$ and $\mathrm{O}_{2}$. Isot. Isot. Environ. Heal. Stud. 1985, 21, 208-210. [CrossRef]

97. Mezyk, S.P.; Neubauer, T.J.; Cooper, W.J.; Peller, J.R. Free-Radical-Induced Oxidative and Reductive Degradation of Sulfa Drugs in Water: Absolute Kinetics and Efficiencies of Hydroxyl Radical and Hydrated Electron Reactions. J. Phys. Chem. A 2007, 111, 9019-9024. [CrossRef]

98. Buxton, G.V.; Greenstock, C.L.; Helman, W.P.; Ross, A.B. Critical Review of Rate Constants for Reactions of Hydrated Electrons, Hydrogen Atoms and Hydroxyl Radicals (OH/O-in Aqueous Solution. J. Phys. Chem. Ref. Data 1988, 17, 513-886. [CrossRef]

99. Nguyen, V.N.H.; Amal, R.; Beydoun, D. Effect of Formate and Methanol on Photoreduction/Removal of Toxic Cadmium Ions Using TiO2 Semiconductor as Photocatalyst. Chem. Eng. Sci. 2003, 58, 4429-4439. [CrossRef]

100. Zhang, J.; Nosaka, Y. Photocatalytic Oxidation Mechanism of Methanol and the Other Reactants in Irradiated TiO2 Aqueous Suspension Investigated by OH Radical Detection. Appl. Catal. B Environ. 2015, 166-167, 32-36. [CrossRef]

101. Baltrusaitis, J.; Jayaweera, P.M.; Grassian, V.H. Sulfur Dioxide Adsorption on $\mathrm{TiO}_{2}$ Nanoparticles: Influence of Particle Size, Coadsorbates, Sample Pretreatment, and Light on Surface Speciation and Surface Coverage. J. Phys. Chem. C 2011, 115, 492-500. [CrossRef]

102. Langhammer, D.; Kullgren, J.; Österlund, L. Photoinduced Adsorption and Oxidation of $\mathrm{SO}_{2}$ on Anatase TiO $\mathrm{A}_{2}(101)$. J. Am. Chem. Soc. 2020, 142, 21767-21774. [CrossRef]

103. Mi, Y.; Weng, Y. Band Alignment and Controllable Electron Migration between Rutile and Anatase TiO 2. Sci. Rep. 2015, 5, 11482. [CrossRef] [PubMed]

104. Nosaka, Y.; Nosaka, A.Y. Reconsideration of Intrinsic Band Alignments within Anatase and Rutile TiO 2 . J. Phys. Chem. Lett. 2016, 7, 431-434. [CrossRef] [PubMed]

105. Kaabeche, O.N.E.H.; Zouaghi, R.; Boukhedoua, S.; Bendjabeur, S.; Sehili, T. A Comparative Study on Photocatalytic Degradation of Pyridinium-Based Ionic Liquid by $\mathrm{TiO}_{2}$ and $\mathrm{ZnO}$ in Aqueous Solution. Int. J. Chem. React. Eng. 2019, 17, 11482. [CrossRef]

106. Wojnárovits, L.; Takács, E. Rate Constants of Sulfate Radical Anion Reactions with Organic Molecules: A Review. Chemosphere 2019, 220, 1014-1032. [CrossRef]

107. Jayson, G.G.; Parsons, B.J.; Swallow, A.J. Some Simple, Highly Reactive, Inorganic Chlorne Derivatives in Aqueous Solution. J. Chem. Soc. Faraday Trans. 1 Phys. Chem. Condens. Phases 1973, 69, 1597-1607.

108. Maji, T.K.; Bagchi, D.; Kar, P.; Karmakar, D.; Pal, S.K. Enhanced Charge Separation through Modulation of Defect-State in Wide Band-Gap Semiconductor for Potential Photocatalysis Application: Ultrafast Spectroscopy and Computational Studies. J. Photochem. Photobiol. A Chem. 2017, 332, 391-398. [CrossRef] 